\title{
Unorden
}

\section{Locomotive business}

How can large companies be the catalyst for SMEs in exporting cleantech?

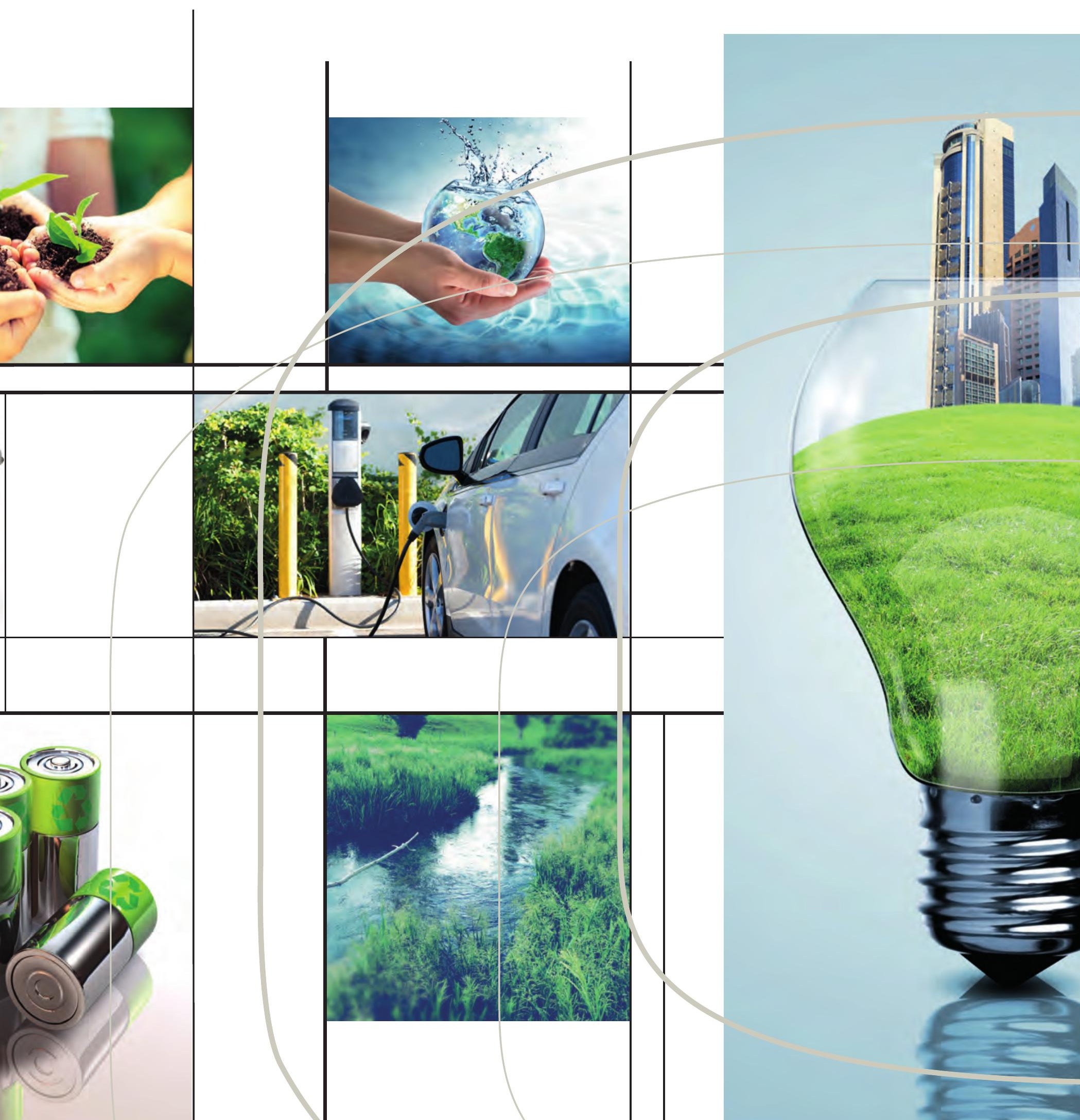



2 norden 



\section{Locomotive business}

How can large companies be the catalyst for SMEs in exporting cleantech?

Christina van Breugel, Henrik Sand, Maria Adenfelt, Daniel Engström, Ulrika Stavlöv, Kati Berninger,

Bernt Sverre Mehammer and Kirsten Møller

TemaNord 2015:532 
Locomotive business

How can large companies be the catalyst for SMEs in exporting cleantech?

Christina van Breugel, Henrik Sand, Maria Adenfelt, Daniel Engström, Ulrika Stavlöv,

Kati Berninger, Bernt Sverre Mehammer and Kirsten Møller

ISBN 978-92-893-4078-6 (PRINT)

ISBN 978-92-893-4080-9 (PDF)

ISBN 978-92-893-4079-3 (EPUB)

http://dx.doi.org/10.6027/TN2015-532

TemaNord 2015:532

ISSN 0908-6692

(C) Nordic Council of Ministers 2015

Layout: Hanne Lebech

Cover photo: ImageSelect

Print: Rosendahls Schultz-Grafisk

Printed in Denmark

This publication has been published with financial support by the Nordic Council of Ministers. However, the contents of this publication do not necessarily reflect the views, policies or recommendations of the Nordic Council of Ministers

\section{www.norden.org/nordpub}

\section{Nordic co-operation}

Nordic co-operation is one of the world's most extensive forms of regional collaboration, involving Denmark, Finland, Iceland, Norway, Sweden, and the Faroe Islands, Greenland, and Åland.

Nordic co-operation has firm traditions in politics, the economy, and culture. It plays an important role in European and international collaboration, and aims at creating a strong Nordic community in a strong Europe.

Nordic co-operation seeks to safeguard Nordic and regional interests and principles in the global community. Common Nordic values help the region solidify its position as one of the world's most innovative and competitive.

\section{Nordic Council of Ministers}

Ved Stranden 18

DK-1061 Copenhagen $\mathrm{K}$

Phone (+45) 33960200

www.norden.org 


\section{Content}

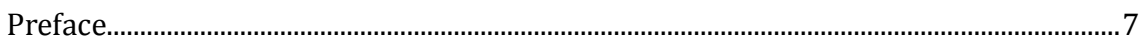

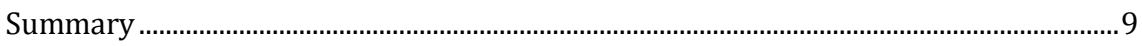

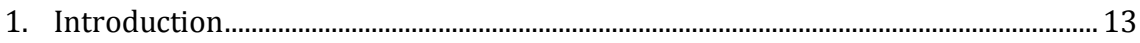

1.1 Context ..................................................................................................................... 13

1.2 Why cleantech?................................................................................................ 14

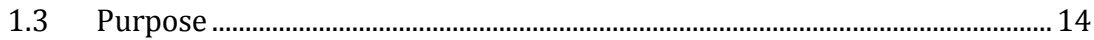

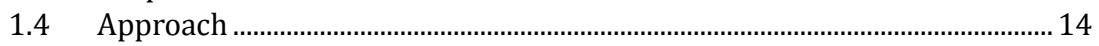

1.5 Outline of the report......................................................................................... 15

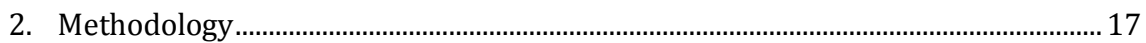

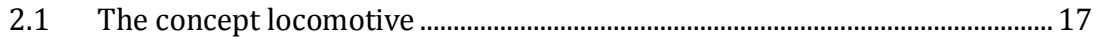

2.2 The concept of system solutions .................................................................... 17

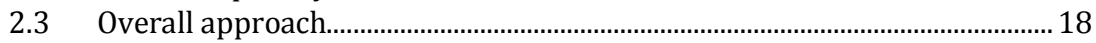

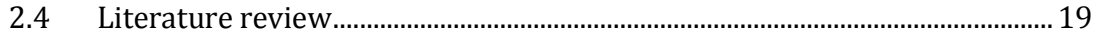

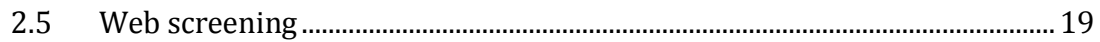

2.6 Public initiative and instrument........................................................................ 20

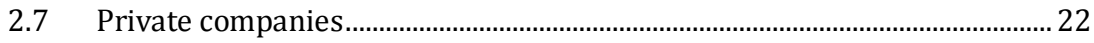

2.8 Best cases - locomotive model ......................................................................... 23

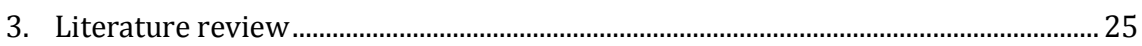

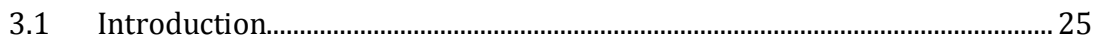

3.2 Export promotion ............................................................................................. 25

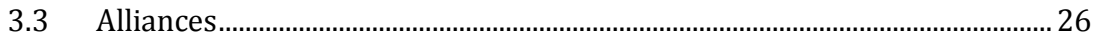

3.4 Conclusions.............................................................................................. 27

4. Overview of the public initiatives in the Nordic countries ....................................... 29

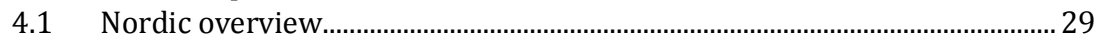

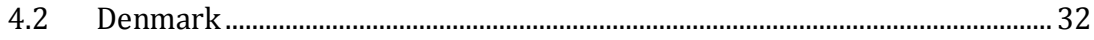

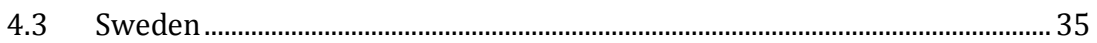

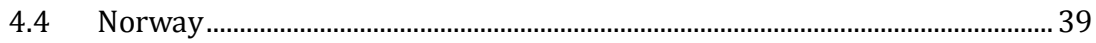

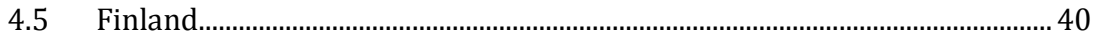

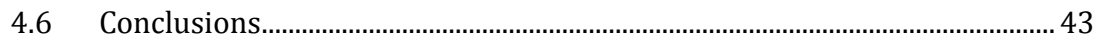

5. Overview of companies in the Nordic Countries..................................................... 45

5.1 Denmark .......................................................................................................... 46

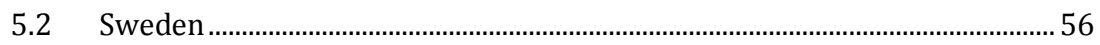

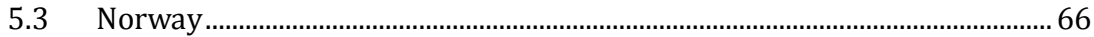

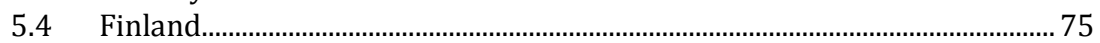

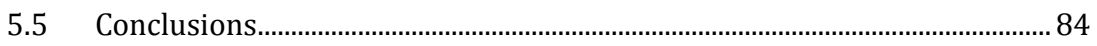

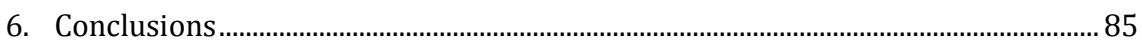

6.1 Overview of the public initiatives in the Nordic Countries ........................... 85

6.2 Overview of companies in the Nordic Countries.............................................. 86

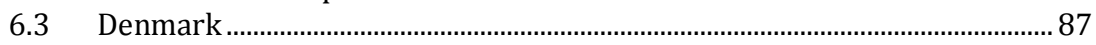

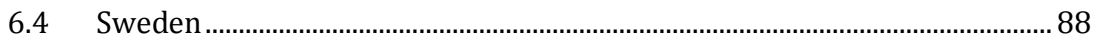

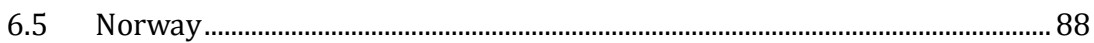

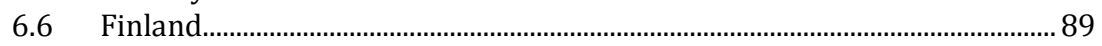

$6.7 \quad$ Locomotive model............................................................................................ 90 
7. Recommendation.......................................................................................................... 93

7.1 Focus on finding the correct companies to partner up.................................. 93

7.2 Find markets for prospective sales.................................................................. 93

7.3 Focus the design and goal of the export promotion programmes............... 94

7.4 Analyse if there are export potentials in strengthening the support

of cooperation between Nordic companies and between Nordic

7.5 Fublic initiatives ........................................................................................

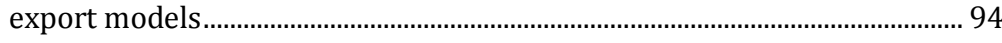

7.6 Develop tools to support the promotion of system solutions ........................ 95

7.7 Provide a broad range of tools allowing for support of all stages of

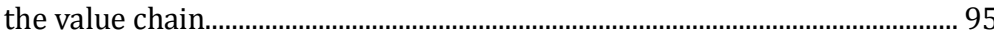

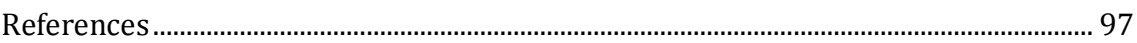

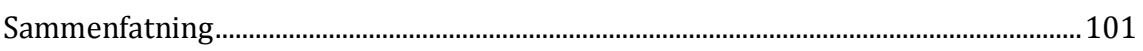




\section{Preface}

The Nordic Council of Ministers' (NCM) Working Group on Sustainable Consumption and Production (SCP) has initiated the project: Locomotive Business - How can large companies be the catalyst for small and mediumsized enterprises in exporting cleantech?

The project aims at developing a better basis for adopting policies on sustainable production of clean technologies and services by improving the understanding of how large businesses can support small and medium-sized enterprises (SMEs) in exporting clean technologies in a Nordic context.

The present project will map instruments used in Denmark, Sweden, Norway and Finland to enhance cooperation between large businesses and SMEs in exporting clean technologies and services in system solutions. The mapping is to be supported by a review and an analysis of existing literature and case studies to allow for a more in-depth understanding of the instruments and the interactions - and for proper dissemination of findings.

The project was carried out from May 2014 to December 2014 by a consortium led by COWI with FORES, Swedish Entrepreneurship Forum and Tyrsky Consulting as partners. The persons working on the project:

- Christina van Breugel (COWI, Denmark, Project Manager).

- Henrik Sand (COWI, Denmark).

- Maria Adenfelt (Swedish Entrepreneurship Forum, Sweden).

- Daniel Engström (FORES, Sweden).

- Ulrika Stavlöv (FORES, Sweden).

- Kati Berninger (Tyrsky Consulting, Finland).

- Bernt Sverre Mehammer (COWI, Norway).

- Kirsten Møller (COWI, Denmark). 
The SCP working group has appointed the following individuals to manage the project deliveries and support the project group:

- Jan Persson, Swedish Agency for Economic and Regional Growth (Tillväxtverket).

- Axel Nekham, Swedish Agency for Economic and Regional Growth (Tillväxtverket).

- Harald Rensvik, Norwegian Ministry of Climate and Environment.

- Ulf Andersson, Swedish Environmental Protection Agency (Naturvårdsverket).

- Martin Svensson, Sweden's innovation agency (Vinnova). 


\section{Summary}

The aim of this project is to explore how public sector support promotes the locomotive model. The model is understood as partnerships between locomotive companies and SMEs in order to facilitate export of cleantech and system solutions. Larger companies often know these SMEs from their existing supply chain.

The approach used in this project was performed in two main steps. Firstly, we carried out an analysis on how public authority initiatives support cooperation on cleantech solutions with locomotive companies. We then interviewed companies to get their perspective of the support instruments. Secondly, a mapping and an analysis were carried out on existing locomotive companies or SMEs, focusing on the possibilities and barriers to how large companies can be the catalyst for small and medium-sized enterprises in exporting cleantech. Best practices and cases are shared and recommendations are provided for designing future public initiatives.

The literature review showed that the collaboration between large firms and SMEs as a policy instrument for export promotion has been given very limited attention. The focus has instead been on the motives and outcomes for these types of collaborations, mainly drawn from research on networks. The lessons learnt for policy makers, if they are to promote locomotives as a means to facilitate SME internationalization, is to support both large firms and SMEs in the establishment of collaboration when it comes to assessment of needs and the complementary skills of the participating actors. Lessons learned for policy makers are to provide support to large and small companies in the design of contracts; both to define the alliance relationship, but also to limit the large firm's access to the entrepreneurial firm's technology. Another lesson concerns the focus of government export promotion programmes. The programmes, which primarily emphasize the provision of "objective" knowledge to recalcitrant exporters, may have to rethink their strategy to focus more on "experiential" knowledge.

The consultation with the authorities showed that support structures vary a lot among the Nordic countries. Only in Denmark is an instrument available that targets each specific area of a company's value chain. Norway has by far the biggest budget, which is mostly spent on Research, Development and Demonstration (RD\&D), which is similar to 
Sweden and Finland. The design of instruments aimed at supporting the early stage of the value chain pushes a strong entrepreneurship culture. The instruments in Denmark are more defined and their goals are clearer. This helps companies know what role they will play in the initiative, what is expected from them and what to expect in terms of support.

Only a few initiatives require cooperation between companies in order to receive funding or support and the terms "locomotive model" and "system solution" were not used.

There is a strong focus on water and energy technologies in Denmark, Norway focuses on energy and Sweden and Finland have no specific focus for its funding.

A main observation was that the various programmes in all Nordic countries had little information on the effect or impacts of the instruments. There were some simple reflections on the number of companies involved and how much monetary funding was used, but few evaluations existed regarding the quantitative or qualitative outcome results.

The consultation with the companies showed that Denmark has a comprehensive instrument inventory, which targets most aspects of the company's value chain. The companies interviewed confirmed that the instruments were living up to the presented expectations. In Sweden, Finland and Norway, there is a large focus on funding the early stage of development, mainly RD\&D. Testing facilities and demonstration projects were well supported in Sweden and Norway. Interviews in Finland and especially Sweden and Norway pointed at the need for having an instrument to target the later stages of the value chain. An example from Finland illustrates that there were possibilities of engaging with the public authorities for having support of the sales phase of the value chain. None of the companies mentioned dissatisfaction with the bureaucracy behind the initiatives or instruments.

The following recommendations are therefore based upon this information and reveal how instruments can be designed to support cleantech companies in entering exports markets together.

Some suggestions for policy makers in the Nordic countries are offered, now with an understanding of the interaction between large businesses and SMEs, which wish to export clean technologies:

- Focus on finding the correct companies to partner up.

- Find markets for prospective sales.

- Focus the design and goal of the export promotion programmes. 
- Analyse if there are export potentials in strengthening the support of cooperation between Nordic companies and between Nordic public initiatives.

- Provide a broad range of tools allowing for support of all stages of the value chain.

- Further conceptualisation of and insight into successful locomotive export models.

- Develop tools to support the promotion of System solutions. 



\section{Introduction}

\subsection{Context}

In a globalised world, exports become increasingly important and open up for the possibilities of countries to specialise their production of goods and services. Exports are especially crucial for smaller economies such as those in the Nordic countries.

If the wish to export is combined with a wish to promote the growth of cleantech sectors, focus should be directed toward optimizing framework conditions that can support businesses in increasing their exports. In this context, framework conditions are to be understood as the environment in which the companies operate, i.e. funding opportunities, regulatory setup, labour force and public initiatives set up to support these activities.

\subsubsection{The Nordic context}

The Nordic countries have few very large businesses and many small enterprises. This is not so different from the rest of the European Union (EU), however, some variation exists among countries.

Large companies have the strength to invest in exploring export potentials, whereas smaller companies are challenged by the lack of necessary resources, skills and knowledge that would allow them to pursue these possibilities to the extent that large companies can. The challenge is to get businesses to approach a broader market and include smaller companies in the solutions. This is the locomotive model.

There has been a trend in the past decades revealing that large companies are well established in export markets and are often not acting as so-called locomotives anymore, at least in the traditional interpretation of the term. Over time, large companies have established themselves in export markets and have built up networks of local suppliers. The need for cooperation with home country companies is therefore not as relevant as it was before. 


\subsection{Why cleantech?}

The term cleantech is used throughout the report and represents environmental technologies and green technologies.

To understand what drives companies to export their cleantech technologies, it is important to identify and analyse their value chain and the cooperation among companies and between companies and public initiatives. This will help to understand what the needs of the companies are. For example, some businesses need to develop new ideas in the RD\&D phase, whereas others need support in how to approach certain markets.

The analysis and mapping will not exclude any type of cooperation on export initiatives. The traditional large locomotive company as well as groups of smaller companies working together are included in the scope. We allow all types of exports, from products to very advanced system solutions.

The public authorities have a number of initiatives and instruments aimed at supporting companies jointly exploring export opportunities. To implement initiatives, instruments are used to target specific areas in a company's value chain. The basis for this analysis will therefore combine the understanding of the characteristics of various instruments and how they align with the value chains of the companies.

The present project will explore the instances where public authorities have played a role in supporting and/or facilitating a certain part of a company's export of cleantech products or services.

\subsection{Purpose}

The aim of this project is to explore how public sector support promotes the locomotive models where large companies are the catalyst for small and medium-sized enterprises in exporting cleantech.

\subsection{Approach}

This project is performed in two main steps. Firstly, an analysis is carried out on how the public authorities in Denmark, Norway, Sweden and Finland support locomotive initiatives. Companies from each country are then interviewed to get their perspective on the public cleantech support. Secondly, a mapping and an analysis are carried out on existing locomotive companies or SMEs on the possibilities and barriers to how 
large businesses can be the catalyst for small and medium-sized enterprises in exporting clean technologies.

We will share best practices and cases and will make recommendations for future public initiatives.

\subsection{Outline of the report}

The report contains the following chapters:

- The methodology provides an explanation of the steps involved in collecting our data, from the initial web screening and literature review to the final discussion (chapter 2).

- The literature review examines the concept of locomotive companies and how they have evolved over time from a theoretical perspective. Furthermore, we have explored export promotion techniques (chapter 3).

- The overview of the public authorities and initiatives in the Nordic countries provides a summary from each country's authority set-up and the information collected through interviews made with the public authorities (chapter 4).

- The overview of companies in the Nordic countries provides the information gained from interviews made with companies selected for support and compares them with the results received from the public interviews. The section also includes cases from each of the four Nordic countries on how exports of cleantech have been conducted through different locomotive models (chapter 5).

- The conclusion sums up our analysed information (chapter 6).

- The recommendation chapter presents in bullet form various recommendations to policy makers when designing instruments (chapter 7). 



\section{Methodology}

\subsection{The concept locomotive}

In the context of our analysis, the locomotive model is broadly defined as either one company or a group of companies that facilitate cooperation with other companies, in order to achieve an increase of cleantech exports.

Traditionally, the term locomotive has been associated with larger companies taking SMEs and their products or services with them to export markets. Larger companies often know these SMEs from their existing supply chain. SMEs can thereby access foreign business relationships through the collaboration with larger firms. Through these business relationships, SMEs can also secure resources and gain essential know-how.

\subsection{The concept of system solutions}

Exports can roughly be divided into two groups. Either a product or service is sold individually or as part of a system solution. The EU defines systems of environmentally sound technologies as total systems which include know-how, procedures, goods and services and equipment as well as organisational and managerial procedures. ${ }^{1}$

In other words, the system consists of more parts. It is not only limited to concrete goods, but it can just as well be services or a combination of these. No limitation exists as to the number of companies that can play a role in a system solution; the share of a company's role is also not specified.

To be regarded as a part of a system solution in this context, there needs to be a formalised cooperation between the partners, not just one company supplying another with its goods or services.

${ }^{1} \operatorname{COM}(2004) 38$. 
A system solution can be categorised into three types or levels: ${ }^{2}$

- The first being goods combined into one product.

- The second being products and services combined into one solution.

- And, finally, a system where the regulatory organisation is included. this could be an urban development project.

In this report, there is no limitation to what is included. The analysis will identify the rationale and lessons learned in the Nordic countries when supporting the cooperation among companies. Based on these findings, we will draw conclusions and make recommendations.

In addition to this, it can be argued that R\&D institutions and financial institutions could be part of a system solution. Examples are seen where a sector precedes an export market from government to government, R\&D to R\&D and business to business. This will help create an understanding of the topic at the different levels and allow the solution to be well understood by the buyers.

\subsection{Overall approach}

In order to carry out as robust analysis as possible, we have performed several data collection steps:

- Firstly, we carried out a literature review to gain a comprehensive understanding of locomotives and the cooperation.

- We carried out a web screening of public initiatives while simultaneously reviewing the relevant scientific literature.

- We mapped and interviewed public authorities about public initiatives and instruments.

- We mapped and interviewed private companies, which had success in exporting their cleantech product or services, either through receiving public authority funding or on their own. 
- We analysed the best cases from each country and made recommendations for policy makers for the future of cleantech exports from the Nordic countries based on all information gathered.

\subsection{Literature review}

Throughout the screening process, we have collected and analysed relevant literature in order to gain a more comprehensive understanding of the problem.

The following questions were formulated based on the literature review and will be used to justify and reflect on the present challenges faced by exports of cleantech from locomotive and SME cooperation:

- What are the common arguments in the literature advocating collaboration between large and small businesses as a way of increasing exports or internationalization?

- What are the advantages and disadvantages of different forms of collaborations?

- What are the desired outcomes of these types of collaborations?

- Which types of instruments are used to promote collaboration?

\subsection{Web screening}

We collected data from public authorities' and company websites. We looked for information on public interventions that best targeted partnerships of locomotive companies and SMEs and attempted to ensure a successful export future for the participating cleantech companies. We collected information regarding the characteristics of various cleantech companies, the type of clean technology they have and their current export share.

We then investigated whether or not they were receiving some form of public support and where in their company value chain this support was targeted. We gathered ample information on public initiatives aimed at supporting the promotion of cleantech exports and partnerships between companies. 


\subsection{Public initiative and instrument}

After the web screening process and the literature review, we collected our information and chose relevant authorities that first had interest in green technology promotion, but also had some form of requirement in place that supported partnerships between companies, or a focus on increasing exports.

Two or three public authorities were chosen for interviews either representing the promotion of exports, supporting cleantech or focusing on the company's interest. Interviews were carried out with the key authority figures and as much information as possible was gathered. To map properly the publicly funded initiatives, we separated the information into four main areas:

- The company or members benefitting from the instrument.

- The characteristic of the instrument.

- The framework surrounding the instrument.

- The documentation of its effect.

We answered and elaborated on any questions we had from the web screening process.

The characteristics of the initiative or instrument were investigated. We analysed among others the requirements for receiving the support, how the support satisfies the needs of the members involved and, importantly, what area of the value chain it targets.

Shown below is an explanation of the areas in the value chain towards which a possible instrument could be targeted.

Figure 1. The value chain

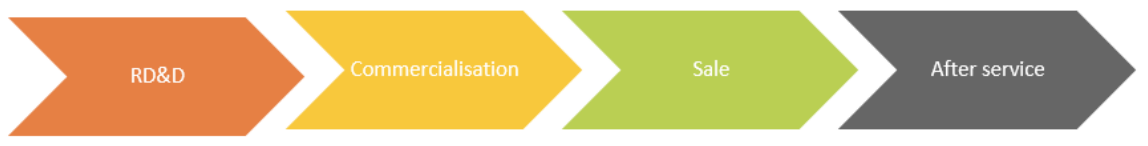

- $R D \& D$ : This phase includes the research, development, test and demonstration.

- Commercialisation: This phase includes production and marketing.

- Sale: This phase includes the introduction of the product and service at the market, both the first and the additional ones. This includes home market and exports as well. 
- After services: This phase includes the maintenance and service provided after sale.

Publicly funded instruments include subsidies, advisory services, loans and guarantees, networking and platforms, education and skill transfer and awareness. We did not limit our project to the analysis of one, but rather aimed at broadly examining where the most effective or highest level of support exists.

The instruments are given in the figure below showing their support in the provided value chain.

Figure 2. The value chain and public instruments

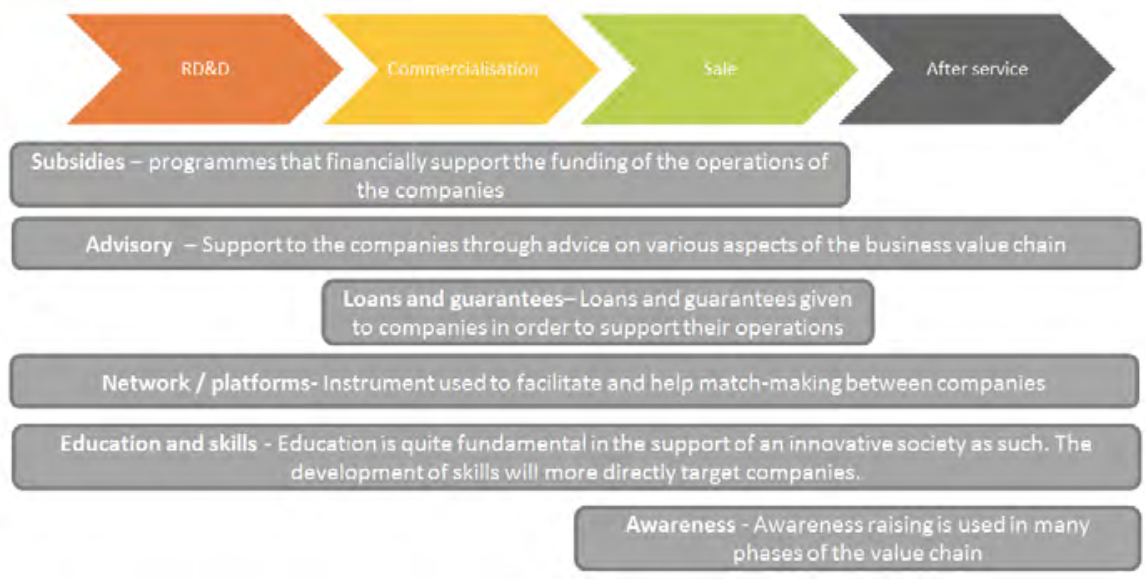

We gathered information on the framework of the instrument. We looked at how the instrument was set-up and if there were any legislative requirements. If it was a politically driven initiative, we assessed how the political context affected the instrument of choice. If the instrument created a link to a locomotive company, this was further analysed.

Finally, we searched for results or evaluations. We focused our efforts on these, as this section provides the evidence of the effect or success of the instrument. If an initiative had been fully implemented, we looked for concrete results and attempted to find out both from the public authority and the participating members how they felt about the success of the instrument.

If an initiative had just started or was still in progress, we attempted to find results until that point and an explanation of how the instrument was going to assist the company in its exports of green technology. This re- 
vealed to be a quite challenging step in the interview process, as many of the initiatives had limited amounts of results and evaluations published.

Overall, these steps provided us with an overview of the initiative from the perspective of the public authorities, which designed it.

\subsection{Private companies}

Through the interview with the public authorities, we began to identify companies who had received funding. We examined the size of the identified companies, their sector and what type of environmental goods they work with; product, service or system solution. In other words, what was the target or purpose of the instrument? Whom was the instrument aiming to attract? To map properly the private companies, we needed to obtain detailed information about:

- The characteristic of the company.

- If they received any public support.

- Barriers from the support.

- Partnerships with SMEs.

Once the companies were mapped, two to three companies were selected for interviews. The criteria for selection were allowed to vary somewhat among the countries, depending on the specific context such as the national sector focus, traditions for export or experience with system solutions.

An interview guide was developed to secure a systematic collection of information and reflections from the companies on the public instruments. The interviews focused on the perception of the instrument and their view on working with other national companies to reach the export markets. 


\subsection{Best cases - locomotive model}

The data from the company interviews was schematically listed to create an overview for the working group and to recommend, which companies to choose as locomotive cases in each country.

An analysis was then carried out for each of the selected companies to examine:

- How effective the locomotive models of cooperation between companies were in influencing the exports of a green technology?

- If a public initiative or instrument had supported the collaboration or the exports of cleantech and how effective it was in achieving its goal?

- How the Nordic countries differ in their public support of the green sector?

As part of the overview, we have recommended to choose cases, which have a clear export focus of cleantech and an obvious collaboration between either a locomotive company or one or more SMEs. One case study was chosen from each of the Nordic countries. 



\section{Literature review}

\subsection{Introduction}

This literature review discusses how the collaboration between large and small and medium-sized companies (SMEs) serves as a means of promoting internationalization. The role of large companies in these types of collaborations is often referred to by export promotion policy makers as locomotives.

There is a widespread assumption that locomotives are large companies that through collaboration with SMEs facilitate their internationalization. This is the point of departure for this brief literature review.

First, we present how the concept is dealt with in different fields of international business literature and, second, drawing on business relations and business network literature, we discuss the collaboration between large companies and SMEs as such.

\subsection{Export promotion}

In the academic literature on export promotion, ${ }^{3}$ the collaboration between large companies and SMEs is less acknowledged. The literature is mainly focusing on the effects of export promotion programmes, such as trade shows and trade missions, on the export performance of SMEs (see e.g. Durmusoglu et al. 2012; Wilkinson \& Brouthers 2006).

A large number of service firms enter foreign markets primarily to serve the foreign subsidiaries of their domestic clients, a phenomenon labelled "client follower" in the international marketing literature (Erramilli \& Rao, 1990).

This group of companies is identified to benefit largely from the experiential knowledge of the company they are following in their internationalization. The study provides further support to the notion that in

${ }^{3}$ Based on a review of articles, published between 2000 and 2014 in high-ranked journals according to ABS. 
committing resources to foreign markets, decision-makers are more influenced by "experiential" than "objective" knowledge.

\subsection{Alliances}

An alliance is defined as "a close collaborative relationship between two, or more firms with the intent of accomplishing mutually compatible goals that would be difficult for each to accomplish alone" (Speakman, Isabella and McAvoy 2000:37). It represents one of two types of external relationships discussed by Street and Cameron (2007).

The other type of external relationship discussed is networks, defined as a collection of relationships that binds a group of independent organisations together (Das \& Teng 2002; Gulati 1998).

Alvarez \& Barney (2001) discuss the benefits of alliances between entrepreneurial and large firms. The identified benefits for large firms are access to new technologies, state-of-the-art engineering talent, and an overall inventive capability (p. 139). The entrepreneurial firm gains a social legitimacy, which is otherwise difficult or time-consuming to achieve. It can also capitalize on the large firm's organizational resources, in for example distribution, marketing and finance, to bring a technology to market.

However, research also shows that over time, entrepreneurial firms can suffer from being in an alliance with a large firm due to value appropriation. New technologies, for example, are embodied in products and processes, making it easier for large firms to learn about them.

The recommendations are to carefully assess the specific gains, in terms of technology and learning, that the respective partners will have from entering an alliance as well as understand the need that each firm is trying to fulfil through the alliance.

\subsubsection{Capabilities and competitiveness}

Baum et al. (2000) suggest that a firm's strategic alliances may influence its capabilities as well as others' perceptions of its capabilities. If a new firm lacks resources and suffers in the market from uncertainty about its products, and if the alliances provide both access to the resources it lacks and favorable signals about the firm as such, then a firm's alliances could work as a buffer against the hazards typically faced by start-ups. 
By forming strategic alliances, start-ups can thus potentially access social, technical and commercial resources that normally require years of operating experience to acquire (Ahuja, 2000).

Small business can increase their competitiveness by forming cooperative relationships with larger firms (Dana 2001:57). This stream of research discusses how entrepreneurs, who link up with larger partners, can reach global markets faster and at a lower cost than through independent expansion.

Other studies witness how large firms, instead of internationalizing via subsidiaries as the preferred means, tend to use other modes to extend their value chain, by way of sub-contracting and franchising. SMEs provide elements of the value chain to larger firms, by way of subcontracting or franchising. This is especially proven the case when SMEs are highly specialized and open up for a niche position.

\subsection{Conclusions}

To sum up, the collaboration between large firms and SMEs as a policy instrument for export promotion has drawn very limited attention in the export promotion literature. The focus has instead been on the motives and outcomes for these types of collaborations, mainly drawn from research on networks.

The lessons learned for policy makers, if they are to promote locomotives as a means to facilitate SME internationalization, are to support both large firms and SMEs in the establishment of collaboration.

Lessons learned for policy makers are to provide support to large and small companies in the design of contracts; both to define the alliance relationship, but also to limit the large firm's access to the entrepreneurial firm's technology. Another lesson concerns the focus of government export promotion programmes. The programmes, which primarily emphasize the provision of "objective" knowledge to recalcitrant exporters, may have to rethink their strategy to focus more on "experiential" knowledge. 



\section{Overview of the public initiatives in the Nordic countries}

\subsection{Nordic overview}

The regulatory set-up for environmental technology funding varies between the Nordic countries. Norway has an abundance of financial funding that is dispersed for all types of cleantech sector support, whereas Denmark has individual programmes aimed at specific value chain support.

The term "locomotive" is not used by public authorities. The identified instruments are designed to support the locomotive model through public initiatives by supporting cooperation between companies. The instruments do not require the solutions to be part of a system, which is why it can be said that system solutions are not a particular goal.

This chapter focuses on the public initiatives in the Nordic countries; first in Denmark, then in Sweden, Norway and Finland. The methodology for selecting the public authorities was based on three main points: there had to be a clear cleantech focus, and either support of cooperation between two or more companies, and focus on exporting the technologies. The public authorities and initiatives identified in the countries, and which have been included in the analysis, are provided in figure 3 .

Through this process, we have identified locomotive companies by analysing, which businesses and cooperation have been supported by public funding to initiate, drive or increase successful exports of environmental technologies. The selection does not require the company to have received public support. However, companies, which have received support, are prioritized, because this study aims at providing policy recommendations for designing initiatives to successfully support the locomotive model. 
Figure 3. Chosen public authorities and initiatives for each Nordic country

\begin{tabular}{|c|c|}
\hline Country & $\begin{array}{l}\text { Public Authority } \\
\text { Initiative/Instrument }\end{array}$ \\
\hline Denmark & $\begin{array}{l}\text { Ministry of Environment } \\
\text { Environmental Technology Development and Demonstration Program MUDP } \\
\text { Business Authority } \\
\text { The Green Transition } \\
\text { Ministry of Foreign Affairs } \\
\text { Trade Council }\end{array}$ \\
\hline Finland & $\begin{array}{l}\text { Ministry of Employment and the Economy } \\
\text { Finnish Funding Agency for Technology and Innovation TEKES } \\
\text { (Green Growth Programme) } \\
\text { Ministry of Employment and the Economy } \\
\text { Finnish Funding Agency for Technology and Innovation TEKES } \\
\text { (Measurement, Monitoring and Environmental Assessment Program MMEA) } \\
\text { Finpro Trade Centre } \\
\text { Export Partner Groups }\end{array}$ \\
\hline Norway & $\begin{array}{l}\text { The Norwegian Government/Ministry of Trade, Industry and Fisheries } \\
\text { Investinor } \\
\begin{array}{c}\text { The Norwegian Government/Ministry of Trade, Industry and Fisheries } \\
\text { Innovation Norway }\end{array}\end{array}$ \\
\hline Sweden & $\begin{array}{c}\text { Ministry of Foreign Affairs/Swedish Foreign Trade Association } \\
\text { Business Sweden (Symbiocity) } \\
\text { Ministry of Enterprise, Energy and Communications } \\
\text { Vinnova (Bygginnovationen) }\end{array}$ \\
\hline
\end{tabular}

In total, we have identified ten initiatives for the Nordic countries that promote cleantech, cooperation and/or export, although more exist. The initiatives analysed were funded mostly on individual areas of their value chain, either RD\&D, commercialisation, sale or after service; very few initiatives covered multiple areas.

The majority of the initiative support comes in the form of financial funding, i.e. loans, grants, subsidies. Further assistance comes from advisory services, market analysis and networking.

Many of the programmes have specific requirements for applicants in that they must have partnerships with one or more companies, in order to receive funding. This encourages cooperation and sharing of 
knowledge, either between a large company and one or more SME's or among a group of SMEs.

System solutions are becoming a popular topic within the cleantech sector. Exporting system solutions is challenging in practice though, as it requires formalised cooperation and is sometimes a very complex solution where the companies are relying heavily on each other.

The major challenge of exporting system solutions and the locomotive model is that it requires the companies to establish a lasting cooperation, where there is a strong need for trust that allows for sharing of ideas and strategies. Building up this trust is time-consuming and companies need to be committed and willing to invest the time.

The following figure presents the targeted value chain area for the different instruments from each country.

\begin{tabular}{|c|c|c|c|c|c|}
\hline & & RD\&D & $\begin{array}{c}\text { Commercialisa- } \\
\text { tion }\end{array}$ & Sale & After Service \\
\hline & & $\begin{array}{l}\text { Research, } \\
\text { Development, } \\
\text { Test and } \\
\text { Demonstration }\end{array}$ & $\begin{array}{l}\text { Production and } \\
\text { Marketing }\end{array}$ & $\begin{array}{l}\text { Introduction of } \\
\text { product or } \\
\text { service to } \\
\text { market (home } \\
\text { and foreign } \\
\text { markets) }\end{array}$ & $\begin{array}{l}\text { Maintenance } \\
\text { and Service }\end{array}$ \\
\hline Country & $\begin{array}{l}\text { Initiative/ } \\
\text { Instrument }\end{array}$ & & & & \\
\hline \multirow{3}{*}{ Denmark } & MUDP & $\begin{array}{l}\text { Financial } \\
\text { Support }\end{array}$ & & & \\
\hline & $\begin{array}{c}\text { The Green } \\
\text { Transition Fund }\end{array}$ & & $\begin{array}{l}\text { Financial } \\
\text { Support }\end{array}$ & $\begin{array}{l}\text { Financial } \\
\text { Support/ } \\
\text { Network }\end{array}$ & \\
\hline & Trade Council & & & $\begin{array}{c}\text { Advisory/ } \\
\text { Awareness }\end{array}$ & \\
\hline \multirow[t]{2}{*}{ Sweden } & Symbiocity & & $\begin{array}{c}\text { Financial } \\
\text { Support / } \\
\text { Advisory/ } \\
\text { Network/ } \\
\text { Awareness }\end{array}$ & & \\
\hline & $\begin{array}{l}\text { BYGGinnova- } \\
\text { tionen }\end{array}$ & & $\begin{array}{l}\text { Financial } \\
\text { Support }\end{array}$ & $\begin{array}{l}\text { Financial } \\
\text { Support }\end{array}$ & \\
\hline \multirow[b]{2}{*}{ Norway } & Investinor & & $\begin{array}{l}\text { Financial } \\
\text { Support }\end{array}$ & $\begin{array}{l}\text { Financial } \\
\text { Support }\end{array}$ & $\begin{array}{l}\text { Education/ } \\
\text { Advisory }\end{array}$ \\
\hline & $\begin{array}{c}\text { Environmental } \\
\text { Technology } \\
\text { Scheme }\end{array}$ & $\begin{array}{l}\text { Financial } \\
\text { Support/ } \\
\text { Advisory }\end{array}$ & $\begin{array}{l}\text { Financial } \\
\text { Support }\end{array}$ & $\begin{array}{l}\text { Financial } \\
\text { Support }\end{array}$ & \\
\hline \multirow{3}{*}{ Finland } & $\begin{array}{l}\text { Green Growth } \\
\text { Programme }\end{array}$ & $\begin{array}{c}\text { Financial } \\
\text { Support/Loans }\end{array}$ & & & \\
\hline & MMEA & $\begin{array}{l}\text { Financial } \\
\text { Support }\end{array}$ & Advisory & & \\
\hline & $\begin{array}{l}\text { Export Partner } \\
\text { Groups }\end{array}$ & & & $\begin{array}{l}\text { Advisory/ } \\
\text { Network }\end{array}$ & \\
\hline
\end{tabular}


The main finding from the screening of the public initiatives is that they have not been evaluated on their effect. So the evaluation of the initiatives is based on a very subjective estimate. Some of the interviewees gave an indication of how they felt about the effect of the programme, but their views are very subjective. The assessment of a programme's success was therefore also dependent upon the interviews with the companies.

A summary of each country's public authority interviews is provided in the following section.

\subsection{Denmark}

The vast majority of public initiative funding for green technologies in Denmark comes from the Ministry of the Environment, the Business Authority, and the Trade Council, which is a part of the Ministry of Foreign Affairs. The Danish Government has committed to a long list of initiatives, all with the purpose of promoting cleantech and research. The figure below shows an overview of Danish exports of cleantech and system solutions, placing the public authorities funding in the corresponding targeted value chain areas. 
Figure 5. Illustration of all instruments supporting cleantech in Denmark and their position in the value chain

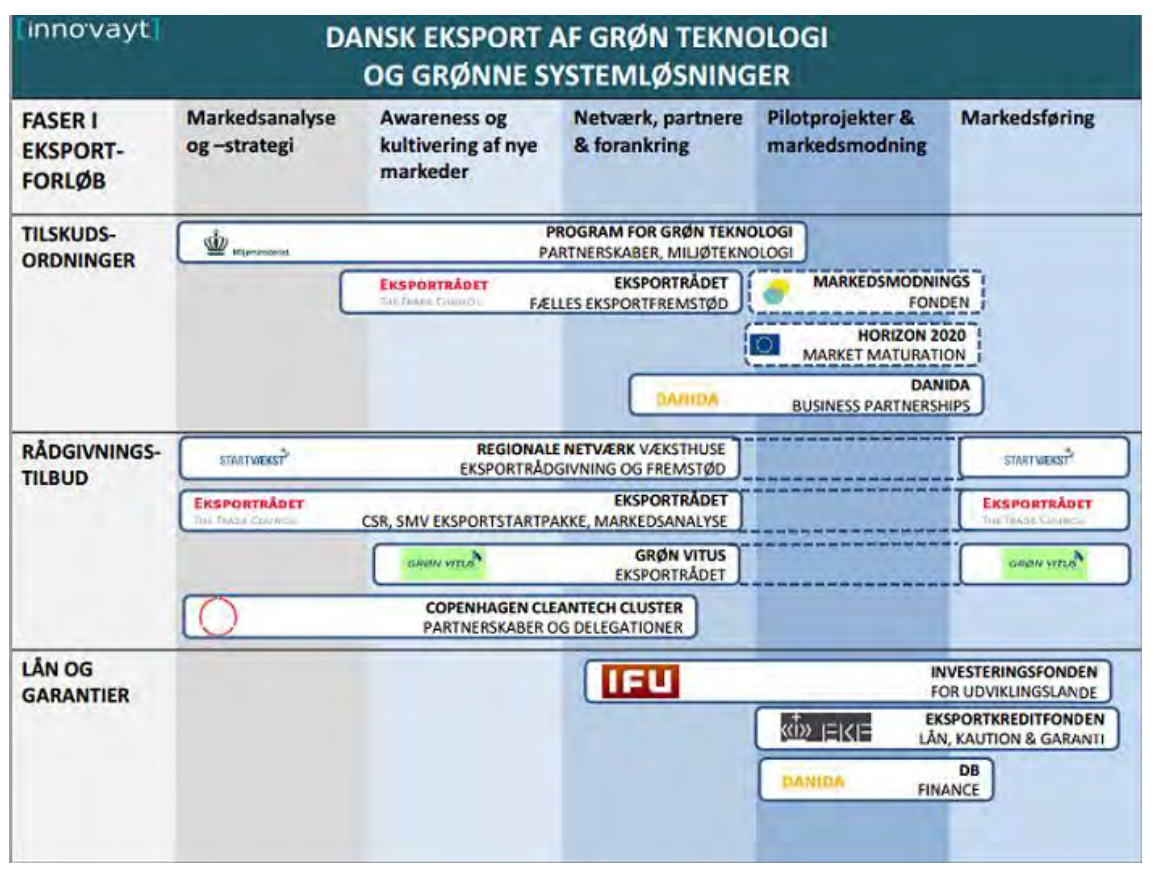

Source: Kruger, Morten. Eksport af grøn teknologi og grønne systemløsninger. Miljøministeriet, Miljøstyrelsen, Innovayt. København, 2013. Accessed 13th July 2014.

http://www.danishwaterforum.dk/activities/Eksportfremmeseminar_121213/Morten-Kruger_ MST\%20-\%20PARTNERSKABER\%20-\%20EKSPORT_handout.pdf.

Denmark is aware of the value chain of the businesses and designs its programmes accordingly, meaning that individual programmes and initiatives are targeted directly at areas which need funding. Overall, the three public authorities in Denmark support the promotion and exports of cleantech in three distinct areas of the value chain: RD\&D, Commercialisation and Sales. ${ }^{4}$

The two initiatives that we give special attention to are the Environmental Technology Development and Demonstration Programme (MUDP) authorized by the Ministry of the Environment and the Green Transition Fund, which is financed by the Danish Business Authority.

\footnotetext{
${ }^{4}$ Kruger, Morten. Eksport af grøn teknologi og grønne systemløsninger. Miljøministeriet, Miljøstyrelsen, Innovayt. København, 2013. Accessed 13th July 2014. http://www.danishwaterforum.dk/activities/Eksportfremmeseminar_121213/Morten-Kruger_MST\%20\%20PARTNERSKABER\%20-\%20EKSPORT_hand out.pdf
} 


\subsubsection{MUDP}

In the last five years, there has been a large increase in public initiatives aimed at promoting the export of clean technologies, and extensive evaluations have been published for the MUDP programme. The MUDP programme provides subsidies for private companies, universities, research institutions and individuals to develop, test, and/or demonstrate environmental technologies and carry out technical feasibility studies.

By providing funding in the RD\&D stage, the programme aims to assist Danish companies in developing novel and affordable environmental technology solutions, that have strong commercial potential, can create green growth through increased exports and solve some of the world's most pressing climate problems. ${ }^{5}$

From 2007-2011, approximately EUR 12.8 million were disbursed to 147 different projects, $85 \%$ of which were in the water, air and waste sector and 32\% had under 50 employees. Another EUR 19 million were disbursed in 2013 and EUR 12.1 million have been set aside for 2014 . This programme has been viewed as a success from both the Ministry of the Environment and a high percentage of the participants. ${ }^{6}$

\subsubsection{Green Transition Fund}

The Green Transition Fund aims to support business development, production, sales and marketing of green products. The funded projects must include a new and inspiring green concept, relevant and competent partnerships, growth and employment impacts, and result in an environmental effect or solution. ${ }^{7}$

While the MUDP funds the RD\&D stage, the Green Transition Fund's purpose is to assist in getting the product or service to an international market within two years by facilitating contacts between relevant companies with similar competencies. ${ }^{8}$ The majority of the participating companies are medium sized (50-250 employees) and projects have

\footnotetext{
${ }^{5}$ Danish Ministry of the Environment (2013). Accessed 13th July 2014. http://eng.mim.dk/

${ }_{6}^{6}$ Miljøministeriet Ecoinnovation. Tilskudsordning til miljøeffektiv teknologi. Miljøstyrelsen. Accessed 13th July 2014. http://ecoinnovation.dk/emneoversigt/isaer-for-virksomheder/finan siering-ogtilskud/tilskudsordning-miljoeteknologi-mst/

${ }^{7}$ Erhvervsstyrelsen. Grøn Omstillingsfond (2014). Accessed 13th July 2014.

http://groenomstilling.erhvervsstyrelsen.dk/gronomstillingsfond

${ }^{8}$ Erhvervsstyrelsen. Grøn Omstillingsfond (2014). Accessed 13th July 2014.

http://groenomstilling.erhvervsstyrelsen.dk/gronomstillingsfond
} 
much shorter time scales than the MUDP. The fund was established in 2013 and will continue through 2016.

\subsubsection{Danish Trade Council}

The Danish Trade Council is responsible for assisting SMEs and large companies in exporting and expanding their activities to new markets by providing strategic sales alliance services. The Trade Council works with foreign governments and public authorities to establish a more exportfriendly framework for Danish cleantech companies. ${ }^{9}$

Their consulting and market analysis services target the sales part of the value chain and are essential for successful export of clean technology products and especially system solutions in the sectors of water and power. Denmark's export of water and environmental technologies makes up about $11 \%$ of its total country exports, bringing in around EUR 11 billion annually. ${ }^{10}$ Implementing Danish total system solutions in developing countries, especially water technologies, is an area of large export potential.

\subsection{Sweden}

In Sweden, there is an overarching strategy "The Swedish environmental technology strategy" 2011-2014. The strategy included a total of SEK 400 million (100 million per year). The strategy aimed, among other things, to:

- promote the export of Swedish environmental technology

- promote research and innovation

- facilitate innovations to be commercialized.

Business Sweden is owned by both the Ministry of Foreign Affairs and the Swedish Foreign Trade Association. Vinnova is a Swedish government agency working under the Ministry of Enterprise, Energy and

\footnotetext{
9 Danish Business Authority (2014). Accessed 13th July 2014. http://danishbusinessauthority.dk/ 10 Ministry of Foreign Affairs of Denmark. Ab out the Trade Council (2014). Accessed on 13th July 2014 http://um.dk/en/tradecouncil/about/
} 
Communications. Both promote innovation and the spread of clean technologies, through various initiatives. ${ }^{11}$

Another example is Cleantech Inn Sweden. It is a non-profit organisation that facilitates early stage cleantech companies and networking with investors, industry and policy makers. It is funded by the Swedish Agency for Economic and Regional Growth (Tillväxtverket)), the Swedish Governmental Agency for Innovation Systems (Vinnova), Västra Götalandsregionen and Region Skåne.12 For this project, we focus on two initiatives; BYGGinnovationen, authorized by Vinnova, and SymbioCity, authorized by Business Sweden.

\subsubsection{BYGGinnovationen}

BYGGinnovationen is co-driven by Vinnova and the industry and provides grants for research and development at universities, institutes, and in small and medium-sized enterprises. The initiative provides grants to facilitate commercialization of knowledge, solutions and research results within Information and Communication Technology, Process Development and Sustainability.

Grants are separated into (a) innovation grants of maximum EUR 5,500 (b) planning grants of maximum EUR 21,800 and (c) project development grants of maximum EUR 218,000. The innovation grant applicants should be SMEs seeking advice from universities and institutes on how to formulate a project proposal that can lead to further support from a planning grant. A group of companies can apply for this, but at least one needs to be an SME.

The planning grant can be used for market analysis, cost-benefit analysis, or mapping of relevant regulation and legislation. The project development grant is devoted to projects that can lead to an innovative product, service or process, which can be introduced to a market within three years after the project is initiated. ${ }^{13}$

The overall purpose of the projects is to develop a strong and sustainable innovation environment in the Swedish cleantech sector. They should further contribute to improved productivity and effectiveness of

\footnotetext{
11 Other authorities working with innovation and commercialization of green technologies include The Energy Agency and Tillväxtverket.

12 http://cleantechinn.com/

13 Vinnova (2014). Utlysning Bygginnovationen 2011-2016. Available at http://www.vinnova.se/EffektaXML/ ImporteradeUtlysningar/2011-02947/Utlysning\%20Nationellt\%20innovationsprogram\%20-

\%20Bygginnovationen_rev20140925.pdf(599759).pdf
} 
the Swedish cleantech sector in a way that strengthens the international competitiveness of the sector. The initiative also strives to create measurable effects on employment and turnover. ${ }^{14}$

The majority of funding is directed towards SMEs seeking to undertake R\&D and facilitating their efforts to commercialize their product. In exceptional cases, larger industries could also receive funding (BYGGinnovationen).

Although BYGGinnovationen does not require a certain level of export success or partnering with companies, export increases usually take place, especially when a specific technological product is produced for a target market.

\subsubsection{SymbioCity}

SymbioCity is a concept that attempts to solve the negative environmental and social impacts of rapid and unplanned urban growth on cities and individuals, by integrating system solutions and improved management of municipal infrastructure. ${ }^{15}$ It is financed by governmental funds and companies from any sector are eligible to apply for support.

SymbioCity uses a "door-opener" policy, meaning that they assist in establishing contacts with local policymakers, as well as in advocating for certain criteria for construction and procurement of various environmental projects.

The initiative supports companies by helping them to advertise sustainable urban system solutions in export markets, thereby creating an interest from potential customers in Swedish companies that can play a part in such a system solution.

SymbioCity can help subsidize services for companies, such as market analysis or by finding partners for small Swedish companies in the exporting country, for example distributers. However, the main focus of SymbioCity is to open doors, create networks, and package and advertise system solutions for sustainable cities.

In addition, Business Sweden tries to influence the early stage of foreign market access by working with governments to influence political decisions, mainly environmental targets or performance standards. The

\footnotetext{
${ }^{14}$ www.bygginnovationen.se

15 http://www.symbiocity.org/en/approach/
} 
selling of the cleantech products are left to the companies, once they have entered the markets.

According to the SymbioCity interviewee Håkan Dahlfors, some companies seem to believe that SymbioCity is to provide assistance at a later stage as well, but this is not the case. He reiterated that SymbioCity is a concept that helps attract interest in Swedish solutions and companies, thereby creating networks with potential future customers.

$\mathrm{Mr}$ Dahlfors mentioned that one difficulty in relying on locomotives for the export of clean technology is that companies are hesitant to invest in projects on other markets since these usually imply a significant risk related to managing a project with a number of involved actors. Swedish embassies repeatedly point out that there is a need for technical solutions to environmental problems in foreign countries, especially in the waste management sector, but companies simply cannot afford the risk associated with the venture.

The Swedish Agency for Growth Policy Analysis (Tillväxtanalys) has been assigned by the Swedish government to develop methods and indicators to measure the effects of public support to promote the internationalization of SMEs. The assignment is ongoing and will be reported in February 2015. In a mid-term report, presented in the end of September 2014 , it was concluded that the government should develop and agree on measurable goals for trade promotion and organisations offering services and their intermediaries should keep a full digital record of which forms use their services. ${ }^{16}$

In 2013, the Swedish National Audit Office issued an audit report that concluded that the government lacks a method to assess the impact of trade promotion services on firms specifically. ${ }^{17}$

\footnotetext{
16 Tillväxtanalys (2014). Effekter av statens främjandeinsatser för internationalisering - utveckling av mätmetoder och indikatorer. Rapport 2014:07.

${ }_{17}$ Riksrevisionen (2013). Heading out into the world - the State's initiatives for promoting export (RiR 2013:10).
} 


\subsection{Norway}

Public initiative funding for green technologies in Norway comes from Innovation Norway and Investinor, both funded by the Norwegian Government.

Innovation Norway is the government's official trade representative abroad and aims to assist Norwegian businesses in growing and finding new markets. They support companies in developing their competitive advantage and innovative solutions by providing advisory, promotional and network services, and financial funding.

Innovation Norway and Investinor have annual budgets of around EUR 470-708 million. Therefore, these public authorities have the ability to fund numerous types of projects and companies in any one of the value chain phases, and sometimes all of them.

The wood and marine sectors automatically receive approximately EUR 60 million each year, as Investinor is intent on supporting Norwegian industry. Investinor has not achieved the rate of return goal in their first five years, but Innovation Norway expects positive returns when projects have reached their full potential.

\subsubsection{Investinor and Innovation Norway}

Investinor is an investment company that invests in promising companies wishing to grow and expand internationally. Investinor was established in 2009 and supports companies from the commercialisation phase of the value chain and follows them through the sale and after service phase.

They invest in all promising projects, from oil and gas to cleantech, and can take up to a maximum of $49 \%$ ownership in the participating companies. They prioritize investments in sectors with companies that have potentially international competitive advantages, that maintain utilization of important natural resources, and that utilize new technologies to mitigate climate change.

The initiatives chosen for Norway that best support cleantech are the Environmental Technology Scheme (ETS), authorized by Innovation Norway, and Investinor's entire investment programme, obviously funded by Investinor. The ETS programme targets the RD\&D stage of a company's value chain, but can also support them financially throughout the commercialisation and sale stages.

Extra financial support is given to companies that are partnering and cooperating with other companies on projects. Companies must first 
show the potential commerciality of their product or service, show the environmental effect of its use and provide residual funding for whatever amount ETS does not cover.

Since the inception of the ETS programme in 2004, it has generated positive results in terms of companies surviving, growing and remaining productive for a minimum of three years after receiving the funding.

\subsection{Finland}

Public initiatives for cleantech growth in Finland are primarily funded through Tekes, the Finnish Funding Agency for Technology and Innovation, which is a part of the Finnish Ministry of Employment \& the Economy.

Finpro is the national trade, internationalisation and investment development organization in Finland. It is a public-private organization, having 550 private company members and also being a part of the Ministry of Employment and the Economy Group. The initiatives focused on here are the Green Growth Programme, authorized by Tekes, the Measurement, Monitoring and Environmental Assessment - innovations through new thinking (MMEA) programme partially funded by Tekes, Cleantech Finland and Export Partner Groups, both authorized by Finpro. ${ }^{18}$

\subsubsection{Tekes}

Tekes is the main public funding organization for research, development and innovation in Finland. In 2013, Tekes gave EUR 577 million to R\&D projects in companies and research organisations, and $67 \%$ of company project funding went to SMEs. Tekes also evaluates the quantity and quality of collaboration between larger companies and SMEs, and between companies and research organizations.

Started in 2011, the Green Growth Programme funds companies and value networks that have growth potential in resource efficiency technologies and in transitioning Finland to a greener economy. Their focus areas are energy and material efficiency, bio-economy and biomaterials,

18 Other initiatives include LADEC, a cleantech park made up of universities and companies that invest and assist in developing environmental technology companies in the Lahti region (http://www.ladec.fi/ladec). Team Finland is made up of numerous government funded organizations to build cross-organizational networks for cooperation (http://vnk.fi/julkaisukansio/2014/j05-tf-strategia2015-06-tf-strategi-07-tfstrategy/pdf/en.pdf). 
and recycling and recovery of raw materials and waste processing. They have a total annual budget of EUR 80 million $50 \%$ of the funding comes from Tekes and 50\% from the companies. The Green Growth Programme has funded fifty companies, $45 \%$ of the companies involved have been SMEs and Tekes itself has funded EUR 30 million.

Half of Tekes funding is allocated according to demand from companies with a clear development plan and a demonstrated willingness to work towards the set objectives. The other half is allocated through the almost 20 programmes in which they are involved, the six SHOK programmes, and strategic research openings.

The Strategic Centre for Science, Technology and Innovation (SHOK) was established in 2006 in order to promote closer cooperation and interaction between business life and research to speed up innovation processes. From 2008 to 2012, EUR 500 million were used on funding research programmes and setting up testing and piloting environments for green technology development.

\subsubsection{MMEA}

The MMEA is a smaller programme under CLEEN, one of the six SHOK programmes. It provides a subsidy that mainly supports research, but also partially supports pilot studies and demonstration. The MMEA programme has a budget of EUR 50 million for the whole programme period, which runs from 2010 to 2015.

About $55 \%$ of the funding come from Tekes and the rest from participating companies and research organisations. A SME typically funds $50 \%$ of its own participation and Tekes funding covers the rest. For large companies, the share of public funding is smaller.

There is much interdisciplinary research and organisations are constantly working together. The intellectual property rights are shared among participants, meaning that any participating company may use the results in its own product development and business outside the programme.

The programme is still ongoing, but at this stage it can be said that the scientific level of the research is high and that there is a lot of international interest. Half of the participating companies are already using the results in their own product development, and it is estimated that all participating companies will use the results when the project terminates.

The interviewee Tero Eklin thought that due to these positive results, the programme has been and will continue to be an overall success. He mentioned Pegasor Ltd. as an example of a company that has maximised 
the use of the opportunities of the programme. It has grown from a sensor and component producer to a producer of instruments and measuring systems and has experienced tremendous export growth in the Chinese market. The pilot study project included a large international company and well-known Finnish research organisations.

\subsubsection{Finpro}

Finpro addresses the coordination and assistance involved in exporting. They support companies through accessing right markets at the right time with competitive concepts, products and services.

Cleantech Finland is a programme under Finpro whose objective is building a Finnish cleantech sector brand, which can be recognized abroad. They collect sales leads, meet with public and private foreign delegations in Finland, and create contacts with foreign investors. They have 85 member companies and about $80 \%$ of them are SMEs with either international operations or a clear strategy for inter-nationalisation.

The interviewee Mika Finska stated that if member companies are satisfied by the services, the programme can be viewed as a success. Satisfaction is measured by annual member surveys, as well as by collecting feedback at various events and during meetings with member companies.

Export Partner Groups is a programme that aims at helping SMEs launch their export activities. They establish cooperation projects, which involve four to six companies that complement each other and that target the same geographical market area. Since its establishment in 1993, about 300 groups have been formed involving over 1000 Finnish SMEs. The objective of the programme is that participating companies could establish their own independent operations in target locations within a two to three year period. This concept has been tested with several cases and the experiences have been mainly positive. They may develop cooperation in product development, procurement, and/or production.

The companies are responsible for developing their businesses once in the markets. This concept is also relatively new within the environmental and green sectors and a couple of companies have already benefitted, including a business purifying contaminated soil.

Overall, a significant amount of public initiative funding in Finland is directed towards RD\&D to promote innovative environmental technology development. The Green Growth Programme revealed a need to move from traditional subcontracting relations to actual partnerships between larger companies and SMEs. 
Furthermore, there is a growing need for market access for products and services developed by SMEs. Initiatives that focus mainly on RD\&D and not commercialisation and sales will be much slower at achieving increased exports. Export Partner Groups addresses the internationalisation activities for Finnish companies, but has only recently focused on environmental technologies. The key to successful cooperation between group member companies is a shared business strategy and an individual who actively strengthens group relations and follows a plan.

\subsection{Conclusions}

In short, the findings from the consultation with the authorities showed the following trends:

- The budgets for funding and support are much higher in Norway compared with the rest of Nordic countries.

- The funding in Denmark is more related to the understanding of the value chain of businesses than for the other Nordic countries.

- The instruments used in Sweden and Finland are designed to target early stage support in the value chain (RD\&D).

- There is no use of the term locomotive model or of the term system solution.

- In Denmark, there is a strong focus on water and energy, in Norway on energy, and in Sweden and Finland there is no particular focus.

- Few of the public initiatives have been evaluated in terms of their purpose and expenditures. The effects of the initiatives are not well investigated and quantitative or qualitative measures are lacking. 



\section{Overview of companies in the Nordic Countries}

This chapter focus is twofold. First, Nordic companies are identified and their perspective on the public initiatives and instruments support in creating growth and increasing export share is assessed. These public initiatives and instruments are described in chapter 4 of this report. Secondly, the locomotive model is described for each of the countries through the individual cases.

The following companies either have either a cleantech solution or are currently partnering with other companies on a cleantech project in a foreign market and have received public authority funding or have ventured into new markets through other ways, which will be further discussed.

An overview of the companies chosen and interviewed from each country is provided in the figure below.

Figure 6. Overview of the companies included in the analysis

\begin{tabular}{|c|c|}
\hline Country & Company \\
\hline \multirow{3}{*}{ Denmark } & DHI Water \& Environment \\
& Aarhus Water \\
& Vestas \\
& Aluwind \\
\hline \multirow{3}{*}{ Sweden } & Scania AB \\
& Malmberg Water AB \\
& Xylem \\
& Skanska \\
& Friegeo \\
\hline \multirow{2}{*}{ Norway } & Borregaard \\
& Tomra \\
\hline \multirow{2}{*}{ Finland } & Pegasor \\
& Vaisala \\
& GreenStream Network \\
\hline
\end{tabular}


Each country section starts with an introduction of its cleantech sector, followed by a summary of the company interviews in which the instruments are assessed from a company perspective. Finally, country sections end with the cases describing the locomotive model.

The introductions are made individually and do not allow for comparison, as the cleantech sector focus varies from country to country. Some of the countries focus on the turnover raised from exports while others are more focused on the sector origins of the companies. This is further challenged by the lack of a common definition of the sector, which also creates uncertainty about direct comparability of the information.

\subsection{Denmark}

\subsubsection{Introduction to the cleantech sector}

In 2009, Denmark's Business Authority research and analysis unit FORUMS identified 720 companies in Denmark, which develop and sell cleantech. These companies have more than 120,000 full-time employees and a turnover of more than EUR 40 billion. The cleantech companies are focused on a variety of environmental challenges. The challenges most companies focus on are climate change, water pollution, air pollution and raw material and material consumption. ${ }^{19}$

Danish exports of water and cleantech account for $11 \%$ of total exports, or close to EUR 11 billion annually. ${ }^{20}$ More than $60 \%$ of the Danish production of water and environmental technologies are exported to foreign markets. ${ }^{21}$ From 2011 to 2012, Denmark increased its exports of water technologies by 7\%, exporting for EUR 2 billion. ${ }^{22}$

The sector is characterized by a few large global companies, such as Grundfos (pumps), Danfoss (cooling and heating) and Vestas (wind energy) that can be seen as locomotives for Danish SMEs. These SMEs are often highly specialized in different areas of water and environmental technologies and often need assistance from public authorities and locomotives to penetrate the high-growth markets abroad.

\footnotetext{
${ }^{19}$ Kortlægning af miljøteknologiske virksomheder i Danmark (FORA, 2009): http://ecoinnovation.dk/media/ecoinnovation/64397/miljoeteknologisk_rapport_online.pdf

${ }^{20}$ http://greetings.um.dk/da/eksportraadet/sektorer/miljoe\%20og\%20vand/

${ }^{21} \mathrm{http}$ //greetings.um.dk/da/eksportraadet/sektorer/miljoe\%20og\%20vand/

22 http://www.gogreenwithaarhus.dk/en/Projekter/Vandtestcenter-samler-nationale-styrker.aspx
} 
The world is facing significant challenges concerning water, the environment, managing natural resources and green technology. These areas are high on the agenda of the Danish government, which is largely because Denmark has a strong position in this area. The aim is to create the framework, support and legislation needed for Danish companies to capture greater global market shares.

For example, close to EUR 7 billion was allocated in 2011 to support the development of new environmental technology and a new national test centre for water technology has now opened in Aarhus which aims to make it easier for water sector businesses to access testing facilities to see if their products work as intended. ${ }^{23}$

The potential for Danish water and environmental solutions is assessed to be very large and it is a particular priority of the Ministry of Foreign Affairs to exploit this potential by increasing demand for Danish products. ${ }^{24}$ The two companies interviewed were DHI Water \& Environment and the water utility company Aarhus Water. The case shows how the locomotive model is implemented in practice, and focuses on the wind sector. This sector has a long tradition of strength and the model is now being used as inspiration to create a similar set-up in the water sector due to the documented success.

\footnotetext{
${ }^{23}$ http://www.gogreenwithaarhus.dk/en/Projekter/Vandtestcenter-samler-nationale-styrker.aspx 24 Vækstplan for vand, bio og miljøløsninger:

http://www.evm.dk/publikationer/2013/ /media/oem/pdf/2013/2013-publikationer/12-03-13vaekstplan-for-vand-bio-og-miljoeloesninger.ashx

LEAN Energy Cluster: http://www.leanenergy.dk/

Strategi for samarbejde om Danmarks klynge- og netværksindsats:

http://www.leanenergy.dk/media/161547/cluster_strategy_dk.pdf

Dansk Miljøteknologi: http://www.danskmiljøteknologi.dk/

Miljøstyrelsen, Miljøprojekt, 2006, Markedet for miljøeffektiv teknologi:

http://www2.mst.dk/common/Udgivramme/Frame.asp?http://www2.mst.dk/Udgiv/publikationer/2006/

87-7052-077-1/html/helepubl.htm
} 


\subsubsection{DHI Water \& Environment}

DHI Water \& Environment 25 provide its own software technology and consulting services broadly within the water sector. DHI also supports water technology manufacturers in developing, testing and documenting their technologies.

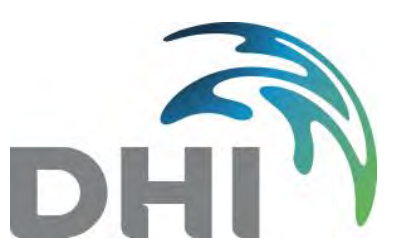

DHI operates in 60-80 countries annually and has experience from more than 140 countries. They therefore have less need for the Trade Council to provide them with market insight. Other companies that do not have contacts would greatly benefit from the Trade Council's services, though DHI finds that the services provided by the Trade Council are too expensive (user fees are too high) and that the quality of services varies.

DHI highlights the Ministry of Environment's MUDP programme as useful because it helps to co-finance projects that show customers from international countries how Danish eco-efficient solutions work. DHI finds that is important for small Danish companies to get assistance, from the MUDP programme.

DHI can be considered a locomotive company, in that it attracts and pulls smaller companies to foreign markets. For example, local water purification treatment plants in Singapore would like to understand how to run the plants efficiently without the need of a large number of employees. DHI consults and advises them on how the plant should be built in order to incorporate both new technologies and new solutions with a lower amount of human capital. If there was a better public incentive structure, then DHI could pull more SMEs along with technological know-how to developing countries that need assistance in water systems.

Financing is often a barrier that makes SMEs reluctant to invest in export initiatives. Private-public initiatives have been initiated to create more funding. These initiatives have been good, but difficult to realize because it simply takes too long to move from developing a product or service to selling it.

25 Illustration: http://worldwide.dhigroup.com/dk/?redirect=www.dhi.dk 
DHI suggests:

- A revolving fund (i.e. loans) to finance specific feasibility studies and thereby making the public support more business driven.

- Better dialogue about export promotion (focus, prioritization, scope).

- Initiatives similar to DANCEE, which were funds for the promotion of Danish environmental technologies, which was a part of the environmental assistance to Eastern Europe after the fall of the wall. This meant that Danish companies gained a good foothold in Eastern Europe.

\subsubsection{Vand}

3Vand (3Water) is a partnership of the three largest water utility companies in Denmark; VandCenterSyd, Aarhus Vand and Hofor. Together, they have a vast knowledge of plant operations, establishing organisations, analysing, expanding, projecting, and carrying out training programmes. ${ }^{26}$

The purpose of 3Vand's international group is to promote and accelerate the development and export of Danish water technologies. ${ }^{27}$ Furthermore, their objective is to promote cost competitive and efficient water solutions within the U.S. water utility industry. In doing so, they aim to expose the possibilities in the U.S. market for Danish water technology solutions, sharpen 3Vand's CSR profile and identify any barriers to development of Danish exports in the water sector. ${ }^{28}$

\subsubsection{Aarhus Water}

Aarhus Water $^{29}$ is water utility company and a part of the 3 Vand partnership. They are currently establishing an export model in Chicago together with the Danish Environmental Protection Agency, the Danish Trade Council and the Danish General Consulate in Chicago. Aarhus Wa-

\footnotetext{
${ }^{26} \mathrm{http}: / /$ www.danishwaterforum.dk/activities/Eksportfremmeseminar_121213/Lars-EskilJensen_Water\%20Technology\%20Alliance\%20i\%20USA.pdf

27 http://www.danishwaterforum.dk/activities/Eksportfremmeseminar_121213/Lars-EskilJensen_Water\%20Technology\%20Alliance\%20i\%20USA.pdf

$28 \mathrm{http}$ //www.danishwaterforum.dk/activities/Eksportfremmeseminar_121213/Lars-EskilJensen_Water\%20Technology\%20Alliance\%20i\%20USA.pdf

${ }^{29}$ http://www.aarhusvand.dk/
} 
ter highlights this cooperation, called the Water Technology Alliance (WTA), as a strong example of how companies and public authorities can create common ground for increasing the export of Danish water technology solutions. This model for cooperation is based on a similar export model used in the Danish wind sector.

\section{aarhusvand}

Figure 7. The vision, mission, strategy and objective of WTA30

\begin{tabular}{|l|l|}
\hline Vision & \begin{tabular}{|l|} 
- Accelerating Danish export of water related \\
technology to The United States of America
\end{tabular} \\
\hline Mission & $\begin{array}{l}\text { - Danish companies export market leading components } \\
\text { via cohesive and flexible product solutions to } \\
\text { U.S. counties. }\end{array}$ \\
\hline Strategy & $\begin{array}{l}\text { - Governmental corporation between } \\
\text { 3 Vand \& Aarhus Vand and U.S. county }\end{array}$ \\
\hline & $\begin{array}{l}\text { - Installation of cost competitive, efficient and sustainable } \\
\text { solutions within the U.S. water technological industry } \\
\text { (utilities) }\end{array}$ \\
\hline Objective
\end{tabular}

The model implies that Aarhus Water has sent their operations manager to Chicago to act as a "water ambassador" for Danish water solutions. It is easier for the water ambassador to build relations to the United States utility companies by acting as a colleague who represents Danish water technologies, instead of a company who uses a sales person.

Therefore, Aarhus Water has also chosen not to commit themselves to a partnership with specific companies. This gives a lot of flexibility

${ }^{30} \mathrm{http}: / /$ www.danishwaterforum.dk/activities/Eksportfremmeseminar_121213/Lars-EskilJensen_Water\%20Technology\%20Alliance\%20i\%20USA.pdf 
and independence, which is necessary to build relationships and trust with the American utility companies.

This "water ambassador" has a strong understanding of Danish water products and solutions and will therefore be in contact with the Metropolitan Water Reclamation District of Greater Chicago to introduce technical water solution concepts. For example, sludge is seen as a cost for U.S. utility companies. In Denmark, Aarhus Water uses Danish clean technology to turn wastewater into energy by producing biogas and heat from sludge.

\section{Figure 8. The role of WTA}

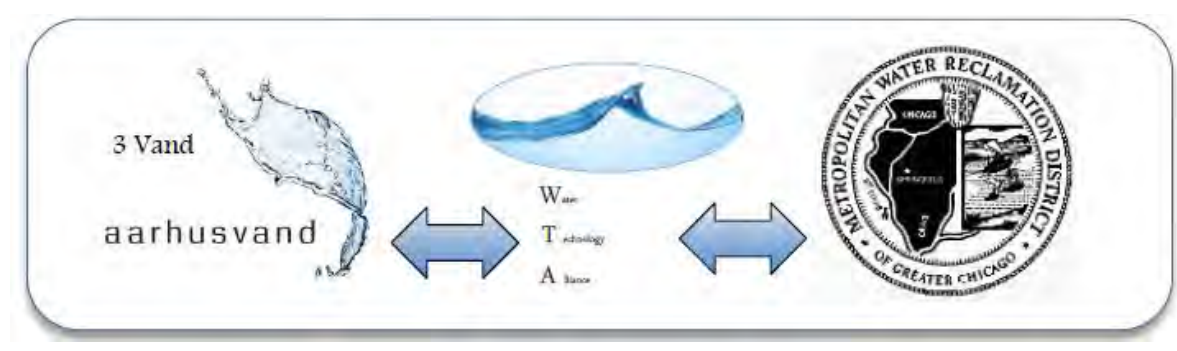

The Water Technology Alliance is a strong and interesting model that aims at increasing Danish water technology exports in the U.S. market, and supporting partnerships between large companies and SMEs. Results will be realized in the coming years.

The challenge for the "water ambassador" will be to balance his role as both independent water expert and promoter of Danish companies. This includes finding the right timing for introducing Danish companies to his relations at the Metropolitan Water Reclamation District of Greater Chicago and other potential buyers of Danish water solutions.

Although this partnership is relatively new, it is an example of how 3 Vand is supporting the development and export of Danish water technologies. 3Vand's international group is also involved in many projects with consultants and entrepreneurs in Southern Asia and Africa and is working hard to create a brand within the next three years as an attractive partner for export of water technologies and international development.

Lars Eskil Jensen, advisor from the Trade Council under the Ministry of Foreign Affairs of Denmark, has made conclusions on the Water Technology Alliance up until now. He highlights in a recent presentation that building this export platform takes time and that financing is absolutely necessary from many different sources, including the Danish Ministry of the Environment and the Trade Council. Furthermore, strong personal engagement and partnership between all actors is important, in order to 
tackle any further changes in the future of the project, for example in the water sector laws. ${ }^{31}$

Both Danish public authorities and Danish cleantech companies find that the global market for water solutions is large. Therefore, Claus Homann, Head of Department at Aarhus Water, says "it will be a strength if water companies and authorities in the Nordic countries work more often and better together with shared export initiatives and new technology solutions". This could possibly also be with the Netherlands, which is a country that has invested significant resources in promoting Dutch solutions in cooperation with authorities and companies.

\subsubsection{The locomotive model in Denmark}

To illustrate how the locomotive model works in the Danish context, the case of Aluwind is presented below. The case was selected because the wind industry in Denmark is of high relevance. Aluwind has Vestas and Siemens Wind Power as locomotives, and Aluwind is cooperating with the North American Wind Energy Advisory (WEA), which is based on a model similar to the Water Technology Alliance (described above) and a part of the Danish Trade Council under the Danish Ministry of Foreign Affairs.

31 http://www.danishwaterforum.dk/activities/Eksportfremmeseminar_121213/Lars-EskilJensen_Water\%20Technology\%20Alliance\%20i\%20USA.pdf 


\section{Text Box 1. The locomotive model in Denmark}

\section{Case: Aluwind}

\section{Background Context}

Aluwind ${ }^{32}$ designs and produces aluminium components and structures for wind turbines. Aluwind was established in 2008 as a spinoff of a Danish wholesaler of aluminium, due to an increase in demand from the global wind energy company Vestas.

Aluwind focuses on the energy industry's requirements for "durable and lightweight products, flexible and cost-efficient production and reliable deliveries" of non-technical offshore structures, nacelle components and tower internals such as platforms (e.g. switchgear and flange inspection platforms in transition pieces), floor panels, shielding, walls, railings, ladders, gates, hatches, sign plates, ventilation ducts, covers, various brackets and holders (www.aluwind.dk).

Aluwind has grown to be a global company with production in Denmark, USA and China to support the European, North American and Asian markets. Their turnover in 2011 was approximately EUR 27 million In 2013, it had grown to approximately EUR 67 million. Their earnings before interest and taxes and number of employees have also grown; Aluwind now has 50 employees in Denmark.

\section{The Model}

The large global energy companies Vestas and Siemens Wind Power have played a significant role as locomotives for Aluwind's global export growth and model for their export success.

When Vestas began increasing their activities in the U.S., Aluwind followed their main client and built a factory in Colorado, where Vestas had their tower factory and a nacelle factory (for the main turbines). A crucial part of this decision was that they had a letter of intent from Vestas, ensuring an attractive turnover for Aluwind if they took the risk of establishing themselves on the U.S. market. The first years proved to be costly for Aluwind, but their return on investment has increased and North America has become a profitable growth market for Aluwind.

Second, they had an investor that believed in the global growth plan, and thirdly they succeeded in attracting highly skilled labour that had the profile needed for securing a globalisation and professionalism in all parts of their organisation, including sales and marketing. This skill level has meant that they can successfully approach all larger energy companies, including GE-Energy and various regional energy companies.

32 Illustration: http://www.aluwind.com/company-profile.html 
As Henrik Jacobsen, Group CEO of Aluwind, states, "it is crucial to have a global set-up, otherwise the large energy companies won't talk to you. Plus, it opens new doors to potential customers on other continents."

Aluwind has through this process expanded their business and become one of three kit-suppliers to Siemens Wind Power. Aluwind has become a strategic partner that sources, picks and packs wind energy components from third party suppliers and physically delivers the various components to specific projects. Aluwind has thereby become a service provider that manages the supply process and needed inventory levels, including the entire management of logistics and procurement for Siemens Wind Power.

This "vertical integration" of being both a global kit-supplier and providing system solutions to Siemens Wind Power has led Aluwind to become a locomotive for other Danish sub-suppliers. These Danish sub-suppliers are now establishing agencies in the U.S. to grow their business in an important market that is closer to their end-customers.

One important part of the model used by Aluwind for increasing their export is a successful cooperation with the North American Wind Energy Advisory (WEA). The WEA group, part of the Danish Trade Council under the Danish Ministry of Foreign Affairs, provides Danish wind energy companies access and a long-term foundation in foreign markets. The business segments WEA mainly focuses on are industrial components, after sale services, power solutions and offshore consultancy.

WEA supported Aluwind in the decision to establish themselves in the U.S. WEA found office facilities and created contacts to partners who could support Aluwind in finding a foothold in a new market. Lately, Aluwind has been using the WEA group to gather information about GE Energy, for which Aluwind is looking to become a component and service provider. This includes information regarding market analysis, company analysis, GE supplier expectations and ideal entry points.

Aluwind acknowledges that WEA has done an extraordinary job researching GE Energy's organisation, which has given critical insight into the market in which they operate. This has enabled Aluwind to approach GE Energy in a much more professional, competent and effective manner.

\section{Purpose}

Aluwind uses aluminium in their product designs, because aluminium is "corrosion-resistant, durable, lightweight, easily worked" and the metal can be melted and re-used and "designed with built-in functions and in larger sections, reducing installation costs and simplifying logistics significantly" (www.aluwind.dk). It has proven to be very useful in the development of more cost-efficient production, operation and maintenance of the wind turbines. 
The wind energy market is a newer market and within the last 10-15 years, wind energy companies have grown their businesses and established their supply chains. Because of its infancy stage, parts of this sector have room for improvement and potential efficiency gains. Siemens Wind Power was therefore first mover when they chose to certify kit-suppliers as a way to source system solutions and to gain more efficiency in their supply chain. Up until then, wind energy companies had managed a significant part of their value chain, including the sourcing from various suppliers.

Trends

Aluwind as a kit-supplier thereby helps Siemens Wind Power focus on their core business activities by outsourcing the management of supplies to a strategic partner, who becomes a focal point for creating a more efficient and coherent supply chain. Aluwind believes that an increasing number of large wind energy companies will begin to find and utilize kit-suppliers, as it would serve as a step toward producing more cost-efficient wind turbines, thereby strengthening wind energy as a feasible alternative to non-renewable energy solutions such oil and gas.

This has also been revealed in the growing offshore wind turbine industry where there is a trend for companies partnering together to share warehouse space by stocking products in the same facility as it is simply too expensive to send spare parts individually, therefore forming partnerships to stock goods together and save on stocking costs is a way to decrease costs and increase sales of spare parts.

\section{Barriers}

A significant amount of subsidies has been provided to the wind energy market. However, governments are contemplating reducing these subsidies. This causes a very fluctuating market, especially in the U.S.

The United States Federal Government has imposed, on individual states, a 25-30\% reduction of $\mathrm{CO}_{2}$ emissions by 2025. The United States has a Federal Production Tax Credit (PTC) in place for wind energy. It is a tool to keep electricity rates low and encourage renewable energy development. A 2.3-cent per kilowatt-hour PTC is in place for electricity generated by wind energy sources, and since its inception in 1992, the credit has been renewed and expanded several times (Source: U.S. Department of Energy, August 2014). If the credit is not renewed, electricity from wind energy is left behind. This uncertainty around PTC makes companies nervous and risk-averse toward further investments. 


\subsection{Sweden}

\subsubsection{Introduction to the cleantech sector}

Below is a short summary of the trends and development in the Swedish cleantech sector between 2003 and 2012, based on the overview of the Swedish Agency for Growth Policy Analysis of the cleantech sector between 2003 and 2011 with updated numbers from Statistics Sweden (SCB). ${ }^{33}$

Statistics Sweden defines a cleantech company as a company "that exists due to the existence of an environmental problem." The numbers do take into account companies that do not have the reduction of environmental damage as a main goal, but which may produce environmental goods, in the development of new technology, compared with a baseline or competitors in the same sector.

In 2012, the cleantech sector employed 69,147 people, corresponding to $2 \%$ of the total employment in Sweden. The largest number was employed in the green service sector, with 23,466 people.

The total turnover of cleantech companies was about EUR 26 billion in 2011. Since 2003, the turnover has increased by around 50\%. The highest turnover was found in energy production, followed by services, water, waste and recycling, and manufacturing.

In 2012, the cleantech sector exported goods and services worth over EUR 4 billion corresponding to 3.2\% of Sweden's total export. The largest portion of export was derived from manufacturing and services. The 2012 green sector export was 69\% higher than in 2003. The largest share of the green sector export in 2011 went to Germany (15\%), followed by Norway (13\%), Denmark (7\%), Finland (6\%), China (6\%) and the United States (5\%).

33 Tillväxtanalys (2012) Statistik om miljösektorn - arbetstillfällen omsättning och export 2003-2011 
Table 1. Overview of the cleantech sector in Sweden, 2012

\begin{tabular}{lrrrr} 
Sector & Employers & No of Employed & Turnover (m SEK) & Export (m SEK) \\
Agriculture, forest, fishing & 4,197 & 4,133 & 10,834 & 44 \\
Manufacturing & 1,055 & 11,786 & 39,584 & 17,882 \\
Energy Production & 1,434 & 4,819 & 61,582 & 2,690 \\
Water, Waste, Recycling & 1,589 & 14,079 & 38,328 & 4,438 \\
Services & 6,848 & 23,466 & 70,851 & 1,455 \\
Public & 829 & 10,248 & 1,674 & 45 \\
HIO/PK & 125 & 634 & 162 & 16 \\
Others & 4 & 1 & 0 & 0 \\
Total & 16,081 & 69,147 & 220,150 & 38,824 \\
\hline
\end{tabular}

Source: Swedish Green Sector 2012 in number, sector per sector. ${ }^{34}$

The companies interviewed from Sweden were Scania AB, Malmberg Water AB, Frigeo, Skanska, Xylem Inc.

The public authority interview with Business Sweden identified SymbioCity as a programme that utilizes a form of locomotive model, in the sense that SymbioCity is a concept of a system solution that requires cooperation between different companies. In the interview with Business Sweden, which is in charge of SymbioCity, a cooperation was mentioned between Scania AB and numerous Swedish SMEs involved in providing infrastructure, consultancy services and delivering biogas. Malmberg Water $\mathrm{AB}$ was the provider of biogas.

During the interviews, it emerged that Studsvik had a strong identity as a locomotive, which is why it was chosen as the case. In the case, emphasis is given to the locomotive model and to how it is used in a Swedish context.

\subsubsection{Scania $A B$}

Scania $A B$ is a global automotive industry manufacturer of trucks and buses. For Scania AB, the Swedish market makes up less than $5 \%$ of their business. Their green technology is biofuel-run buses and trucks, and these vehicles have been exported to Scandinavian countries in large numbers, but exports to developing countries are increasing partly because of political uncertainties in Scandinavian countries about the economic conditions for biofuel-based transportation.

34 SCB (2014). Miljösektorn per branschgrupp, 2013. Available 2014-10-20 http://www.scb.se/sv_/Hittastatistik/Statistik-efter-amne/Miljo/Miljoekonomi-och-hallbar-utveckling/Miljorakenskaper/38164/ 38171/Miljosektorn/324496/ 


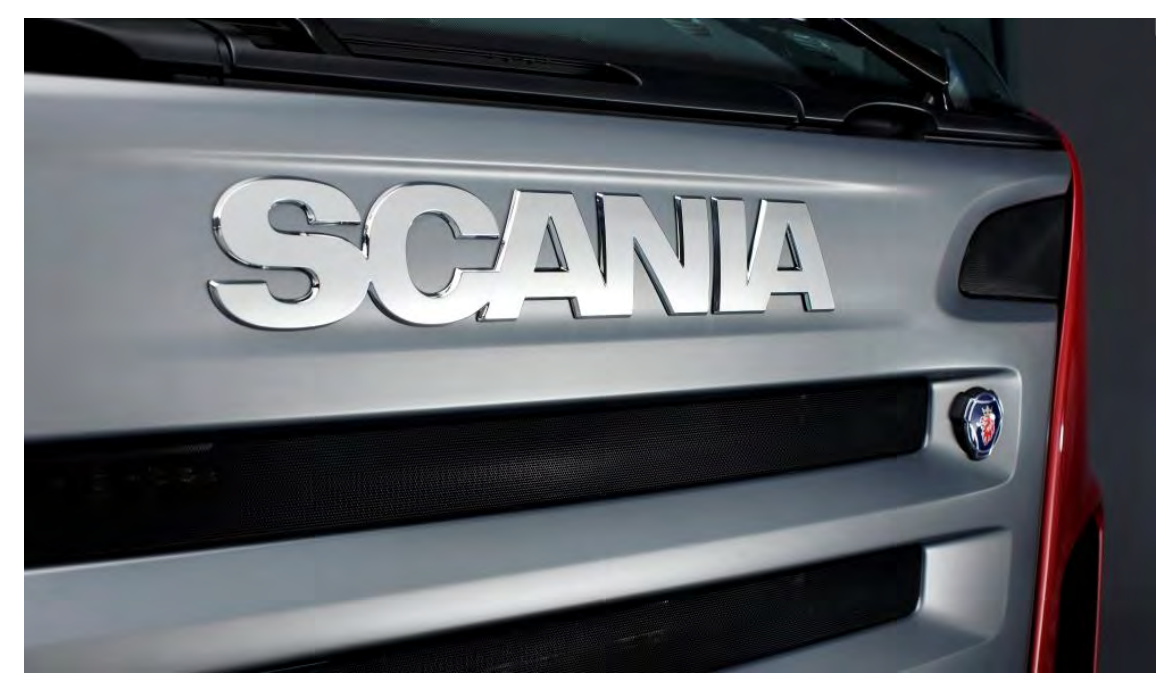

The interview with Jonas Strömberg, director sustainable solutions at Scania $A B$ shed light on the SymbioCity programme from their perspective. Scania AB feels that after the initial door opening that has been the role of SymbioCity, there is a strong need for support in the commercialization phase; the early door opener stage needs to be complemented with a second phase where local actors can build on their local network to facilitate deals.

A robust local network is crucial in making contracts and in many cases, the representatives from Business Sweden simply did not have access to appropriate networks.

One possible explanation for this according to Strömberg could be the large circulation of employees in local offices, citing "a local network is built over a longer period - it is very hard for people only staying in a country a year or two to build a sufficient network."Furthermore, according to Strömberg the SymbioCity experts do not have the substantive local market knowledge that is needed to fully access these markets and profit from exports.

Overall, Scania AB therefore feels that the concept of SymbioCity is broad and difficult to translate into concrete projects. They tend to partner with SMEs when it comes to finding biofuel suppliers, but these are usually local producers and not necessarily Swedish. As Håkan Dahlfors from Business Sweden mentioned in the interview, this is in line with the common misconception that SymbioCity is to play a role also at a later stage, which at the moment is not part of the SymbioCity task. 


\subsubsection{Malmberg Water $A B$}

Malmberg Water $A B^{35}$ is a water purification and gas company that has four main business areas including water treatment, biogas, geothermal energy and drilling. They have about 150 employees, and their net sales in 2013 were EUR 55 million, 70\% of their turnover come from exports. ${ }^{36}$

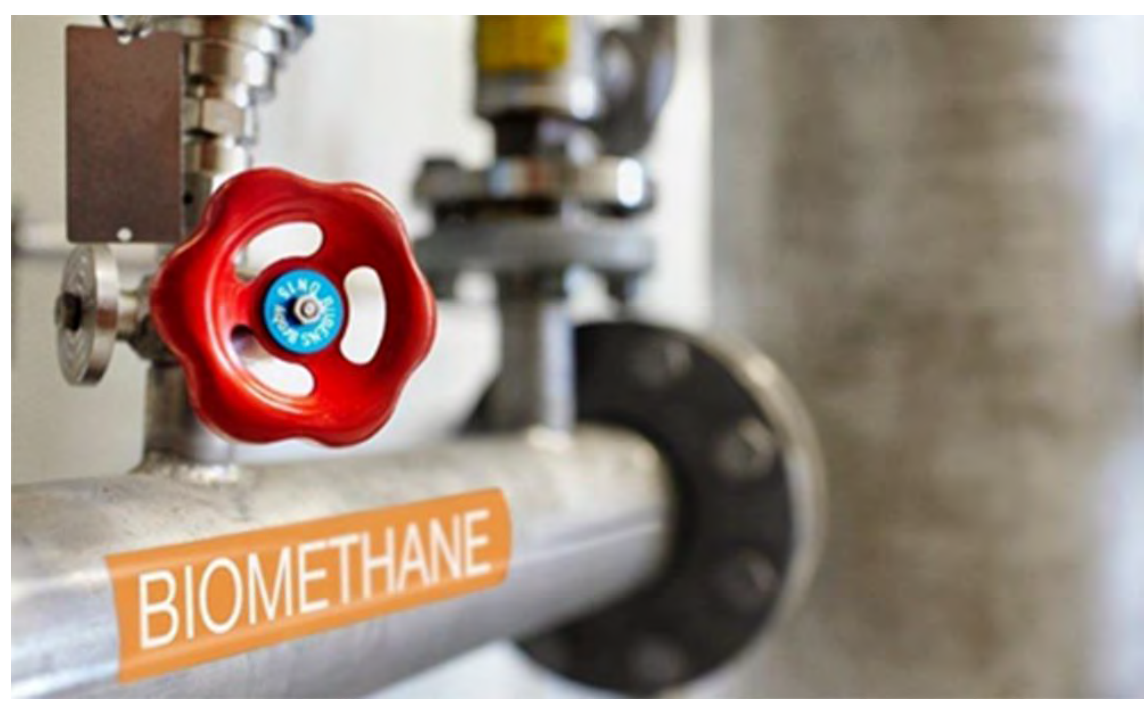

Business Sweden also identified the company in the SymbioCity concept as a SME that could play a part in a sustainable urban transport solution.

Johan Möllerström, Managing Director at Malmberg Water AB, did not believe SymbioCity helped them in increasing their exports or finding new markets. His perception was that SymbioCity has not lived up to its fundamental support concept of creating foreign networks and feels that SymbioCity "is a concept that is impossible for one company to deliver", meaning that the concept is so broad and difficult to grasp that it is hard for Swedish companies to see what their role is.

Möllerström's overall perspective on public authority support in Sweden is that Swedish companies suffer from the lack of a national strategy, and he also highlighted targeted aid as a policy tool used by other countries. Hearing this critique, Håkan Dahlfors once again highlights SymbioCity as a concept set to attract interest from potential customers, rather than providing a done deal for companies.

35 Illustration: http://www.malmberg.se/malmberg

36 http://www.malmberg.se/malmberg/om_oss 


\subsubsection{Xylem}

Xylem $^{37}$ specializes in water technology, including drain and wastewater pumps. It was another company named in the SymbioCity interview. Christian Wiklund, vice president at Xylem, gave some insight into the unfamiliar term of locomotive. The word locomotive is frequently used from public authorities, but it is not entirely clear for Xylem what is expected from them.

\section{xylem \\ Let's Solve Water}

The interviewee gives two suggestions for stimulating locomotives. The first is that everything needs to be business driven, meaning that it is unlikely that a company would act as a locomotive unless there is an obvious business in doing so. Public initiatives could help finance coordination that may facilitate locomotive-driven partnerships. There is also a risk that any organised cooperation may feel forced and unwelcomed. Secondly, SMEs may require more help to market themselves towards possible locomotives. This includes both funding for research and development including demonstration, as well as facilitating the SMEs understanding of how their niche product or service may fit in.

\subsubsection{Skanska}

Skanska ${ }^{38}$ is a world leading project development and construction group and has had great success in globalizing and accessing foreign markets. Skanska has a home market strategy meaning that Skanska has a local presence on each home market and therefore primarily works with suppliers and subcontractors present in that market.

\section{SKANSKA}

37 Illustration: http://www.xylemwatersolutions.com/scs/sweden/sv-se/Sidor/default.aspx

$38 \mathrm{http}: / /$ www.skanska.com/ 
Roughly 50\% of Skanska Sweden's turnover stem from public procurement. ${ }^{39}$ The public authority interview with BYGGinnovationen named Skanska as one of the larger companies that had received funding for one of their environmental technologies, and that in general could function as a locomotive.

Up until early 2000, Skanska cooperated with Swedish entities in Sweden to create clusters, in order to win projects abroad. Johan Gerklev, the sustainability manager at Skanska, thinks it would be wise for public funding to focus on establishing connections between companies on a local level. By having a number of reference projects locally, it would be easier for Swedish clusters to go abroad and win procurements.

Therefore, the idea of national locomotives may be outdated, as local clustering is more valuable. Furthermore, Gerklev feels public procurement and environmental regulation should be a key component in helping stimulate development of new green technologies, which leads to an increase in exports.

A list of green technology start-ups or SMEs should be made on a national level, and larger companies should be encouraged to use them as contractors as part of a publicly procured contract.

\subsubsection{Frigeo}

Frigeo $^{40}$ is a small company with three fulltime employees, but which at times have around thirty people hired for convening projects. Frigeo offers three types of products or methods, including freeze dewatering, freeze dredging and a variety of object rescue and sampling tools.

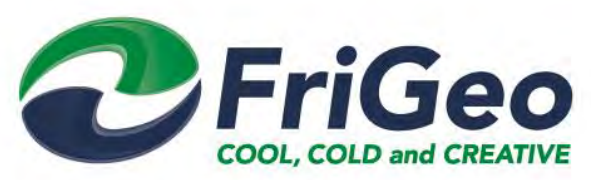

All products provided by Frigeo are able to dewater and separate contaminated sludge. Once the water is extracted from the solids separated out, the remaining sludge can be used for biofuel.

Frigeo has a unique technique for separating oil and nuclear waste from sludge. BYGGinnovationen has been essential in helping them de-

\footnotetext{
${ }^{39}$ Interview with Johan Gerklev, sustainability manager at Skanska, 12th August 2014.

40 Illustration: http://www.frigeo.se/
} 
velop the technique. Frigeo claims that the current development of the company, including reaching new markets, would not have been possible without the support of BYGGinnovationen. They were crucial in supporting the testing and demonstration phase, which enabled Frigeo to prove that their method was successful and reliable.

Jens Eriksson at Frigeo highlighted that the assistance in finding the right partner was crucial, as "it is a necessity to partner up with larger companies in order to reach export markets. We do not have the financial muscles to do the necessary scouting on new markets. It would require us to hire more staff, which at an early stage of a SME is almost impossible."

\subsubsection{The locomotive model in Sweden}

The case of Frigeo and Studsvik presented below illustrates how the locomotive model has worked in a Swedish context. The case was selected due to it being a cooperation between a large company and a SME, who together have benefitted from BYGGinnovationen's support.

\section{Text Box 2. Case illustration the Swedish approach to the locomotive model}

\section{Case: Frigeo and Studsvik ${ }^{41}$}

\section{Background context}

Frigeo is a small company from Luleå, with three to five full-time key employees. Frigeo has developed a technology, which offers three types of methods for separating substances and extracting water from sludge in different forms. The technology has primarily been used for separating oil from sludge and for separating water from sewage sludge. The technology provides for a safer decontamination of contaminated areas, also under water. By separating liquids from the sludge, it also improves the "heat value" of the sludge, making it more beneficial to use the sludge for biofuels, in cooperation with amongst other companies. 42

As a recent example of the cooperation, Studsvik arranged for Frigeo to present their technology in the U.K. to more than 150 key persons from the nuclear sector in the U.K. and the U.S. This has already led to negotiations for around ten projects.

41 The case study is based on interviews with Jens Eriksson at Frigeo on the 4th and 29th September 2014, and interview with Björn Amcoff head of Sales at Studsvik on the 22nd September 2014.

42 Interview Jens Eriksson, 4th September 2014. 
As of yet, it is hard to quantify the export resulting from the cooperation. Nuclear market share of Frigeo's total market is about 15-17\%, but mainly on domestic markets at the moment. Over the coming years, after the support from Studsvik, they will have more intense focus on the U.K. and the U.S. and are currently undertaking negotiations for a number of projects.

\section{Purpose}

The cooperation between Frigeo and Studsvik is strictly business, customer driven and driven by mutual dependence. It can be summed up by the words of Jens Eriksson at Frigeo: "Frigeo is part of a larger jigsaw puzzle, where we provide a technology that can help Studsvik win projects abroad, thereby opening up new markets for Frigeo."

Frigeo provides an application that helps Studsvik to provide a custom tailored solution, in particular for decontaminating old nuclear research and development facilities. The technology from Frigeo secures a safer way of moving contaminated sediments to the Studsvik facilities where the remainder of the decontamination process is undertaken. The remainder of the process is still "complicated", but with the know-how of Studsvik, the technology from Frigeo gets a new area of operation.

For Frigeo, the relationship with Studsvik provides an opportunity to reach new markets, both in terms of using the technology in new areas, but also reaching markets where Frigeo is not present but where Studsvik is well represented. For Frigeo with its limited personnel, it would not be possible to receive sufficient knowledge about potential export markets without a larger company. Frigeo also has the necessary knowledge on environmental regulation and other domestic regulations needed in order to establish on a new market. In essence, Frigeo has the technology; Studsvik can provide most other things needed for establishment on new markets. 
The technology has benefitted from two grants from Vinnova's initiative BYGGinnovationen. The first grant, about EUR 27,000 in 2012 helped Frigeo to identify the technical, environmental and social prerequisites for allowing the dry freeze technology to replace the traditional method of drying sludge. A second grant of about EUR 136,000 in 2012-2013 helped Frigeo to provide further information on the benefits of the technology concerning sewage sludge. During the time of the project, Frigeo also intensified their contacts with a number of larger companies, including Ragnsells and Studsvik. The latter company opened a new market for Frigeo in two senses; for once it became known that the technology could also be used for a third type of decontamination - nuclear waste; and as a consequence, Frigeo was also able to through Studsvik to demonstrate their technology in the US and the UK. 43

For Frigeo, the export is limited at the moment, after a few years with focus on the Swedish market, but the cooperation with Studsvik has meant focus on the UK and US market, and Frigeo foresees a large increase in export over the coming years. Studsvik is specialized in nuclear waste and $75 \%$ of their businesses are dependent on foreign customers.

\section{The model}

The initial and very informal contact between Frigeo and Studsvik was taken several years ago, during a seminar. The formal partnership between Studsvik and Frigeo was set up in 2013 and is hence a rather new partnership working without direct public intervention and financed by the partners themselves. The partnership is currently taking concrete form in a three-year cooperation agreement, stating that Studsvik is to be Frigeo's only representative on nuclear markets. In addition to the formal contract, Jens Eriksson at Frigeo that the partnership is based on mutual trust and need of each other's competences. Studsvik is according to Frigeo showing great respect for the size and need of Frigeo and they fully trust Studsvik to promote their interest in contacts with potential customers. 


\section{Trends}

Studsvik is operating primarily in Sweden, Germany, the U.K., the U.S. and France. In the U.K., the U.S. and to some extent France, a number of large nuclear research and development facilities are growing old and are about to be phased out. Any phase-out of nuclear facilities will require a comprehensive decontamination process, where the technology and know-how of Frigeo and Studsvik will provide for opportunities for new projects. If the technology proves to be efficient in ongoing projects, the chances of larger projects are considerable.

In addition to nuclear, Frigeo also sees great potential in other areas of their technology, participating in ongoing partnerships with other companies. However, the nuclear sector is where the greatest export opportunities are most likely to be found.

\section{Expectations}

The cooperation as well as the technology is still at an early stage, with more demonstration projects needed. Given the developments in the U.K. and the U.S., the expectations for winning future projects are relatively high. Therefore, both parties hope to continue and develop the cooperation. At the moment, a number of negotiations are ongoing and according to Frigeo it would be sufficient to get $10 \%$ of the deals, in order for 2015 and onwards to be "very busy".

\section{Barriers}

The support from BYGGinnovationen for development and demonstration has been incremental in facilitating the cooperation between Frigeo and Studsvik. The grant from BYGGinnovationen proved to be insufficient for the large-scale demonstration that Frigeo had hoped for, although the grant helped reach a state where larger companies came to be interested in developing the technology further. Frigeo says that once there is a tested product, the contacts will come automatically, and the larger companies usually have sufficient amounts of contacts. The advice from Frigeo would be to focus more on public support for research, development and demonstration.

From the Studsvik perspective, large-scale demonstration projects are crucial for the possibility to export a technology. It is not always sufficient to have demonstration projects on the domestic level, but often it is required to show the effectiveness of a technology on foreign ground. Although Studsvik is ready to take some risk in funding demonstration projects, the general feeling from interviews made with Studsvik as well as other companies, is that funding of demonstration projects would be essential for facilitating cooperation between SMEs and larger companies on export markets. 


\subsection{Norway}

\subsubsection{Introduction to the cleantech sector}

The cleantech sector consists of companies that are focused on the business opportunities in the development and production of cleantech and environmentally friendly solutions. ${ }^{44}$

The number of companies in the greentech industry in Norway is changing constantly, but it is estimated to be almost 1,800 businesses in 2011 with more than 38,000 employees and total labour costs amounting to more than EUR 3 billion. With a value added of around EUR 7.6 billion in 2011, cleantech is slightly larger than tourism and smaller than the telecom and information technology sector. The turnover in 2011 was around EUR 21.5 billion All numbers are shown in Table 2.

Table 2. Key numbers for the Green Tech Industry in Norway, 2011

\begin{tabular}{|c|c|c|c|c|c|}
\hline & $\begin{array}{l}\text { No of } \\
\text { companies }\end{array}$ & $\frac{\text { Turnover (NOK }}{1000)}$ & $\frac{\text { Value added }}{\text { (NOK 1000) }}$ & $\frac{\text { Labour Costs }}{\text { (NOK 1000) }}$ & No of Employees \\
\hline \multicolumn{6}{|l|}{ RENEWABLE ENERGY } \\
\hline Hydro-production & 594 & 54823101 & 30850973 & 5500040 & 7513 \\
\hline Hydro technology & 33 & 3454327 & 979364 & 746570 & 1149 \\
\hline Bioenergy & 155 & 4572891 & 1304638 & 622741 & 936 \\
\hline Wind production & 15 & 49471 & 24700 & 26919 & 21 \\
\hline Wind manufactoring and technology & 33 & 2099078 & 567218 & 551229 & 811 \\
\hline Solar & 30 & 9768223 & 711383 & 1849720 & 2386 \\
\hline Other & 22 & 2261260 & 797734 & 156949 & 172 \\
\hline Subtotal & 882 & 77028351 & 35236010 & 9454168 & 12988 \\
\hline \multicolumn{6}{|l|}{ ENVIRONMENTAL TECHNOLOGY AND SERVICES } \\
\hline Consulting, R\&D, ICT & 102 & 7630486 & 4200825 & 3801077 & 5211 \\
\hline Energy efficiency & 96 & 4150006 & 1080668 & 904741 & 1532 \\
\hline Industrial/transport emission management, CCS & 27 & 2140308 & 525094 & 229633 & 260 \\
\hline Environmental monitoring & 11 & 326709 & 147385 & 126872 & 180 \\
\hline Subtotal & 236 & 14247509 & 5953972 & 5062323 & 7183 \\
\hline \multicolumn{6}{|l|}{ TRADITIONAL ENVIRONMENTAL SERVICES } \\
\hline Waste management, treatment and recycling & 475 & 27812318 & 8204113 & 4977931 & 8871 \\
\hline \multicolumn{6}{|l|}{ POWER DISTRIBUTION AND TRADING } \\
\hline Power distribution and trading & 193 & 61768503 & 14870543 & 5850933 & 9574 \\
\hline Total & 1786 & 180856681 & 64264638 & 25345355 & 38616 \\
\hline
\end{tabular}

Source: MENON (2013) The Norwegian Cleantech Industry - Statistics.

44 Menon and Intpow Report no 01/2013. The Norwegian Cleantech Industry - Statistics 2011

http://intpow.com/index.php?id=1759\&download=1 
Waste handling and recycling, hydropower and power distribution and trading are mature businesses in Norway. Almost all energy production in Norway is renewable, and almost $50 \%$ of the value added comes from the hydro energy sector.

In 2011, it was estimated that the cleantech industry in Norway exported goods and services valued at EUR 2.6 billion. Almost $40 \%$ of the export value from the cleantech industry came from the solar segment, while another $25 \%$ was related to the export of electricity.

The selection of companies to interview, in order to assess the value of the public initiatives, showed to be more challenging because many of the companies work alone and the public initiatives support many R\&D projects, which result in relevant companies being more difficult to identify than in the other countries.

The companies selected were Borregaard and Tomra. Borregaard is a bio-refinery company and Tomra provides solutions to resource optimisation. They both have received support for the R\&D phase of their projects.

\subsubsection{Borregaard ASA}

Borregaard $A S A^{45}$ was one of the companies chosen for company interviews. It is a bio-refinery company specialising in cellulose, lignin, ethanol and bio-chemical production.

\section{整 Borregaard}

All products are made from bio-resources, mainly wood and their export share is $98 \%$. They have over 1,000 employees and operating profits of around EUR 61 million.

Borregaard receives public funding through various authorities for different projects and initiatives; about 50\% from Forskningsrådet, 25\% from Innovasion Norge and 25\% from EU Seventh Framework Programme (FP7). The support is mainly directed towards the early stage in the companies' value chain, more specifically RD\&D in cleantech products, although some funding is directed towards more environmental friendly production processes.

45 Illustration: http://www.borregaard.com/ 
An example of direct early stage funding was given to Borregaard from Innovasion Norge to build a test factory for production of bioethanol and advanced bio-chemicals. The total costs of building the factory was EUR 16.6 million and Innovasion Norge financed around EUR 7 million. The environmental friendly production processes are being supported by Enova, a government company owned by the Norwegian Ministry of Petroleum and Energy.

Borregaard received support from Enova to invest in the renovation of their drainage systems at their factory, resulting in both clean waste flows from industrial processes and production of biogas. Enova is constantly supporting production and consumption energy savings projects with about EUR 2.4 million funding.

Borregaard mainly works with businesses and institutions purely as purchasers or providers of goods and services. However, Borregaard also cooperates with the Norwegian University of Life Science (Oslo) and Norwegian University of Science and Technology (Oslo). Both of these are large technical institutes, and the partnerships are facilitated by the government through joint project support from Forskningsrådet and Innovasion Norge.

Borregaard has partnered with Green Biologics, which is a small company out of the U.K. that specialises in providing more sustainable and higher value chemical and bio-fuel products compared to petroleum-based ones. Green Biologics has around 50 employees, most of them working on R\&D or pilot plant production projects. ${ }^{46}$ These two companies use their individual competencies and cooperate on the development of new green bio-fuel products, and both received funding from their own governments.

Borregaard is satisfied with the instruments aimed at assisting the early stage in the value chain. The financial support towards R\&D and test factories has not only relieved the company of funding large investments on their own, but has also given them momentum to increase their own funding, in order to develop these new products that would otherwise have been significantly delayed or not developed at all.

Today, Innovasion Norge and Forskningsrådet usually fund $20-30 \%$ of a research project. However, other EU countries receive around 50\% funding from their public authorities, which Borregaard would like Norway to do as well, especially since $50 \%$ funding for research expens-

${ }^{46}$ http://www.greenbiologics.com/faq.php 
es are within the regulations of the European Economic Area. For example, Green Biologics received 50\% funding from the U.K. Technology Strategy Board, while Borregaard received 25\% funding from Innovasion Norge.

An area of improvement Borregaard would like to see in public funding from Norway is more support in the commercialisation of new products and investments for full-scale production units. This will help get new cleantech products to the market and increase exports for Norwegian companies.

\subsubsection{Tomra Systems ASA}

Tomra Systems $A S A^{47}$ is a global provider of advanced solutions in resource optimization, from sourcing to usage to recovery and finally recycling and revitalizing. 48

\section{A TOMRA}

The company is divided into two main divisions. One is the collection division, which constitutes two thirds of their business and contains reverse vending machines, compaction technology and material recovery. The second is the sorting solution division, which contains optical sensor-based sorting technologies that are used in recycling facilities, food handling and mining practices. The results from food handling and mining are greener because food-handling practices increase productivity and produce higher yields and mining solutions come in the form of large reductions in water, chemical and energy usage.

The most important funding Tomra receives is SkatteFUNN, which is a tax refund instrument, administered through Forskningsrådet, aimed only at promoting R\&D. A business can receive a refund of up to $20 \%$ of their R\&D spending. The main goal of this instrument is to increase $R \& D$ in Norwegian businesses, and this has absolutely been the case for Tom$\mathrm{ra}$, as they have increased their share of R\&D spending due to the effect of this instrument.

47 Illustration: http://www.tomra.com/

$48 \mathrm{http}$ ///www.tomra.com/en/about-us/our-mission 
Tomra has partnered with several businesses. One of the partnerships aims to develop new spectroscopy technology by teaming up with the companies Prediktor and Nyborg, and with research institutes SINTEF and Firmware Design. Furthermore, Tomra is partnering with the Swedish company Enics, which can be seen as a Nordic partnership, to provide a wide variety of life cycle services. Almost all partnerships Tomra ventures into are initiated by Tomra, and they focus on close cooperation with local suppliers for business services and technical solutions. They perceive all of their partnerships positively.

Tomra is satisfied with the early stage placement of the instrument in the value chain. They feel that their personal risk in investing in R\&D is reduced when they receive support from public funding. However, according to the interviewee, support for the commercialisation of the new products is lacking.

The positive results from the $R \& D$ phase are not utilized further, due to high levels of risk associated with testing the product on other markets and preparing the product or service for market. Tomra would therefore appreciate more assistance in later stages of the value chain and also noted that instruments aimed at reducing risk of expanding production to emerging economies and developing countries could be introduced. They propose that this could be done by joining efforts with Norfund or other foreign aid instruments aimed at business development.

\subsubsection{The locomotive model in Norway}

The case of Wärtsilä presented below illustrates how the locomotive model has worked in a Norwegian context. The case was selected due to it being a cooperation build on a cluster. 
Text Box 3. Case illustration the Norwegian approach to the locomotive model

Case: Wärtsilä

Background context

Wärtsilä is an export company within green maritime technology with focus on energy saving solutions.

According to Wärtsilä's web pages, they are a global leader in complete lifecycle power solutions for the marine and energy markets and have almost 19,000 employees globally. Wärtsilä has four subsidiaries in Norway; Wärtsilä Norway, Wärtsilä Ship Design Norway, Wärtsilä Oil \& Gas Systems and Wärtsilä Moss, with a total of 1,200 employees. About 850 of these employees work in the maritime sector. Wärtsilä's primary activities in Norway are R\&D, project management, engineering, manufacturing and sales for Ship Power solutions - including Ship Design - to customers all over the world, as well as sales and execution of a wide array of services for Norwegian customers operating ships and offshore installations at home or abroad.

Their green product is energy efficient vessels and solutions to achieve a decline in maritime NOX and SOX emissions. They have specialised in engine efficiency, but also provide environmental friendly solutions throughout the whole lifecycle of a ship, from the concept stage, through construction, operation and upgrading of older ships. An example of Wärtsilä's green services, is the newly developed Low Loss Hybrid energy system, which was launched in August this year. This system has been tested earlier this year, and confirmed actual fuels savings of $15 \%$.

Wärtsilä's turnover in Norway is approximately NOK 2 billion annually. A considerable amount of Wärtsilä ships is used as supply ships in offshore oil and gas production, which is a global market where the ships are used in all parts of the world.

\section{The model}

Wärtsilä is member of the cluster Maritime CleanTech West (MCTW) and does not like the other cases take the role of a locomotive company. MCTW was founded in 2011, and consists of 31 members. The Cluster is engaged in building arenas and networks for creating forward-looking, innovative and competitive solutions in the maritime sector that reduce environmentally harmful emissions to air and sea. Most of the members are businesses, but there is also a university and a naval base. The smallest business has 1 employee, while the largest has more than 1,500 employees. They are based on the Norwegian west coast, between Bergen and Stavanger. The cluster represents a different way of organising the cooperation of companies in exploring export opportunities. 
The maritime industry in Norway has an export share of about $50 \%$, and constitutes about $20 \%$ of Norway's mainland export (excluding oil and gas export). It is among the most export intensive industries in Norway, and the MCTW main market is global.

The members of the cluster come from the whole supply chain, and the cluster includes all parts of the Norwegian Maritime industry. The maritime sector operates in a global market, and most of the services and products can be considered export.

Because of high costs in Norway compared to the maritime industry in other parts of the world, the Norwegian maritime sector cannot compete on price. The members of MCTW have to come up with better solutions than foreign competitors to justify higher prices they need to cover higher costs. Environmental friendly green technology has been a priority area for the Norwegian maritime industry and they deliver high-end solutions for the world market. The members are aware that they all need a strong cluster to be able to perform on a worldclass level.

Servogear is a mid-size company with 50 employees and a member of MCTW. They develop energy saving propellers, motion control systems and gear boxes for vessels. Their services are developed and tested in Norway, and then exported to the world market. In a news article from March 2014, Petter Martens, Chief Technician in Servogear says, "We are in direct dialogue with market leading businesses and ship buyers through the MCTW. When we meet this way, we come up with creative ideas and solutions."

The partnership was initiated by the business community itself, and it has received support from governmental institutions. They meet on a monthly basis and the partnership is mostly financed by the members. The partnership is currently administrated by Innovasjon Norge, a Norwegian Government instrument for innovation and development of Norwegian enterprises and industry.

MCTW is a part of The Norwegian Centres of Expertise Programme (NCE), which is a cluster programme by the Norwegian Government. NCE is established to enhance sustainable innovation and internationalization processes in the most dynamic and growth-oriented Norwegian clusters. The NCE is set up to increase innovation and export shares, and the Government offer financial and technical assistance for the clusters. Not all NCE clusters have a green profile, so the NCE instrument is an innovation instrument rather than a green instrument. 


\section{Purpose}

The main goal of the MCTW is to increase environmental friendly innovation, exploit the broad maritime knowledge base in the area and to increase export of green technology solutions for the cluster members. It is also used as a tool for joint applications for governmental support.

The partnership works as a catalyst for feasible green projects. It is an environment for sharing ideas and an acknowledgment that the maritime industry is much stronger when they work together. Some members compete in the same market, and have to be careful with what information they share. However, many members are suppliers and buyers of products of the other members, thus have a common interest in the success of each other.

Mr Ingve Sørfonn describes it as a magnet; a force that joins ship buyers, ship builders, research institutes and downstream businesses to create greener solutions throughout the maritime sector.

Maritime energy saving solutions consist of many different technical innovations, including bow shape technology, engine efficiency, weight reducing measures, hull condition management, propeller technology, waste heat recovery and ship system management. The cluster members represent all areas of energy saving maritime technology.

The partnership is also used for joint applications for support from governmental instruments. In many cases, a joint application is stronger than individual ones. Therefore, the partnership generates more public support than the businesses would manage without the cooperation. And some funds are also made available through the cluster. The governmental support generated through the partnership is located early in the value chain. Most support is received in R\&D activity, and especially in the demo and test pilot projects. These phases have very high expenses, and the support works as a risk reliever for the businesses, and thus increase innovation.

The cluster focuses also on the bigger businesses. The maritime cluster is capital intensive, and R\&D in green technology is expensive. Thus, a large part of the innovation is only possible in larger entities with financial muscles to carry out expensive projects.

The partnership also facilitates closer contact between producers and (current and potential) buyers. The businesses in MCTW provide high-end green maritime products and services, and demanding ship buyers in the cluster are considered an asset. They push the business to increasing innovation. 


\section{Trends}

The Norwegian economy has been through two decades of strong growth, only briefly interrupted by the financial crisis in 2008. This growth is partly caused by high activity in the oil sector, where both the oil industry and the manufacturing industry that supplies the oil production, has had very good years behind them.

This growth has led to a rise in salaries in Norway, and labour costs are now among the highest in the world. Engineers and other innovative trades have been in high demand by the oil related industries, and their salaries are today especially high.

Because of the high costs in the Norwegian economy, the industries operating in more traditional export activity have declined in recent years. Higher costs than on the global market mean that the Norwegian businesses need higher productivity to survive. This has been a serious challenge for export activity that is not related to the oil sector.

Since most activity in the oil sector hardly can be called green, it has seen less innovation activity in the green sector recent years. The new situation with declining oil prices and expected lower oil investments in Norway, may lead to more investments in other sectors. With the huge knowledge base in oil related industries that will be available for other industries, it is likely that the energy sector will absorb some of this competence.

\section{Expectations}

The businesses involved expect increased green innovation through information and idea sharing. Often great ideas can come across in other parts of the supply chain, where they are not utilised. Through the partnership, such knowledge is shared.

It is an expectation that through the partnership, the whole maritime industry on the west coast will be stronger, and be among the world's top clusters in the maritime sector. It is also expected to facilitate communication between businesses, research institutions and the relevant government institutions. 


\section{Barriers}

Green technology is expensive to develop, and as long as non-environmental friendly solutions are cheaper, it is a difficult market to operate in. Stronger politics towards environmental friendly solutions would be very much welcomed by the businesses in MCTW. For instance, higher pricing of harmful emissions would shift demand towards green products, and thus increase green innovation.

The partnership considers the lack of environmental focus in political decisions as a barrier. Many businesses work in a long-term perspective, and the lack of predictability and commitment in politics can also be seen as a barrier.

In general, businesses are satisfied that most of the governmental support is placed early in the production process. It is mostly in the R\&D phase and in the early commercialisation process where financial support is needed. However, some of the larger businesses have experienced that the governmental instruments have had too much focus on smaller businesses and left little for the larger ones. This has changed through "Miljøteknologiordningen" from Innovasjon Norge, which also provides financial support to large businesses in the green sector. This change is welcomed by Wärtsilä.

\subsection{Finland}

\subsubsection{Introduction to the cleantech sector}

In Finland, over 2,000 enterprises are active in the cleantech sector (Finpro 2014). The annual turnover of the Finnish cleantech sector has developed from EUR 17.6 billion in 2008 to EUR 25.8 billion in 2013 (Cleantech Finland 2014b, Figure 10). In 2012, the growth rate of cleantech turnover was as high as $15 \%$, but it moderated somewhat in 2013.49

\footnotetext{
${ }^{49}$ Finpro (2014). Invest in Finland. Industries: Cleantech. www-page http://www.investinfinland.fi/industries/cleantech/18 Viewed 27.6.2014 http://www.investinfinland.fi/industries/cleantech/18 Viewed 27th July 2014 Cleantech Finland (2014a). About Cleantech Finland. www.page.com http://www.cleantechfinland.com/content/about-cleantech-finland Viewed 27th July 2014 Cleantech Finland (2014b). Development of Cleantech Industry in Finland 2014. 5th Annual Survey of Finnish Cleantech Industry. http://www.slideshare.net/cleantechfinland/cleantech-industry-in-finland-2014 Viewed 27th July 2014.
} 
Figure 10. Development of Cleantech turnover in Finland between 2008 and 2013

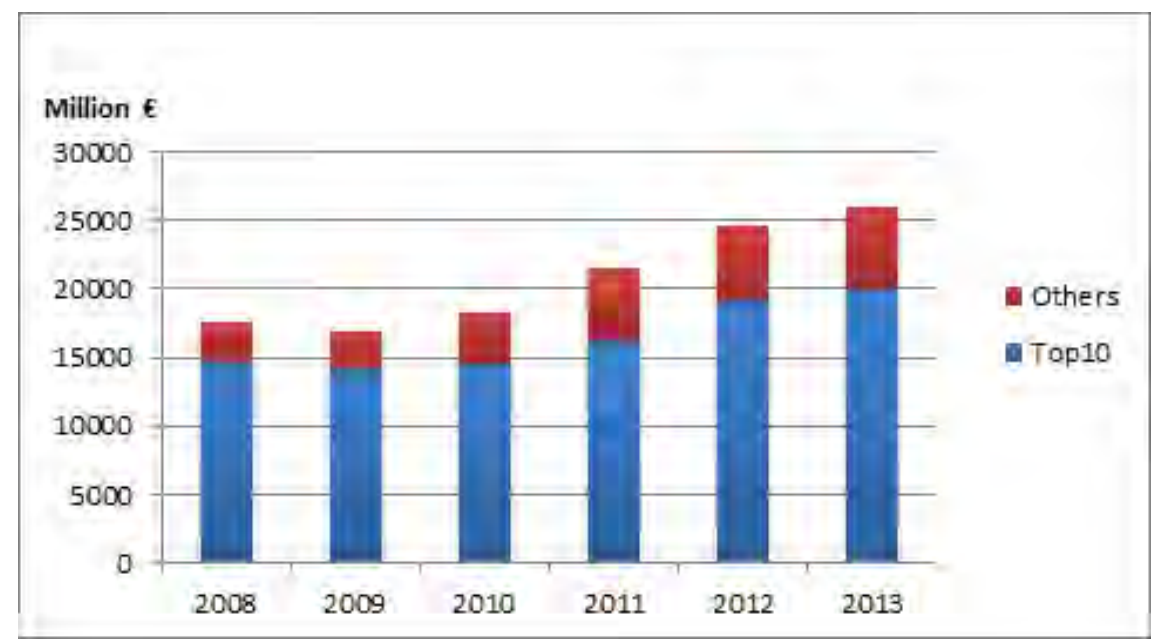

(Cleantech Finland 2014b). Top10 represents 10 largest cleantech companies: Wärtsilä, Metso, Neste Oil, Outotec, Kemira, YIT, ABB, Kuusakoski, Outokumpu and Cargotec (Cleantech Finland 2014a).

$53 \%$ of the total cleantech turnover of Finnish companies came from exports, and $40 \%$ came from the activities of Finnish companies abroad. The key cleantech markets for Finnish companies are Sweden, Germany, Russia, UK and China. The largest cleantech business area is energy efficiency, which can be seen below in table 2 (Cleantech Finland 2014b).

Table 3. Business areas of the Finnish cleantech sector (Cleantech Finland 2014b). The same company may represent several sectors

\begin{tabular}{lr} 
Energy efficiency & \% of companies \\
Clean processes, materials, products & 53 \\
Renewable energy & 39 \\
Consulting & 33 \\
Waste management & 32 \\
Recycling & 23 \\
Other & 23 \\
Water management & 23 \\
Green building & 21 \\
Air protection & 21 \\
Measuring and analysis & 14 \\
\hline
\end{tabular}

Source: Cleantech Finland 2014b.

Growth obstacles of the cleantech sector have been identified as the small size of the Finnish companies, lack of international expertise or capacity to enter export markets, the weakness of the domestic market, and the lack of public support for commercialisation. The strength of the 
Finnish cleantech sector is strong innovative thinking and high level of technology (Cleantech Finland 2014b).

Most of the 2,000 Finnish cleantech enterprises are SMEs, but the ten largest cleantech enterprises account for about $77 \%$ of the turnover of the cleantech sector (Cleantech Finland 2014b, Figure 1). The larger companies are well established, whereas many small cleantech enterprises are relatively young.

In the following section, the companies, Vaisala and Pegasor were interviewed as to their views on the public programme and later a case was developed to describe how the locomotive model is applied.

\subsubsection{Vaisala}

Vaisala $^{50}$ is a locomotive type company involved in the MMEA program. The company produces meteorological and environmental measuring instruments, measuring systems and services.

\section{VAISALA}

Vaisala's Heikki Turtiainen (Technology Manager) has been involved with the MMEA programme since its inception and is now the chairperson of the programme's steering group.

\footnotetext{
"This type of cooperation has enabled building up a large consortium, which means new types of interdisciplinary research groups with companies and research organisations working together. The intellectual property rights are shared among participants. That means that any participating company may use the results in its own product development and business. Competitors may take part in strategic research and after that develop their own business outside the program."
}

Furthermore, the programme has created cooperation with SMEs and Vaisala has had large success in creating new contacts in the Chinese market.

Heikki Turtiainen feels that a possible barrier in this programme is that funding only goes toward research, but the product development

50 Illustration: http://www.vaisala.com/en/Pages/default.aspx 
and commercialization phase is not included. This could be a problem affecting SMEs, but actually it does not have a big impact on a large company like Vaisala. In comparison to conventional Tekes programmes, the MMEA programme has broadened the cooperation network of Vaisala. In a large network, they have found new contacts, which would not have been made without the programme.

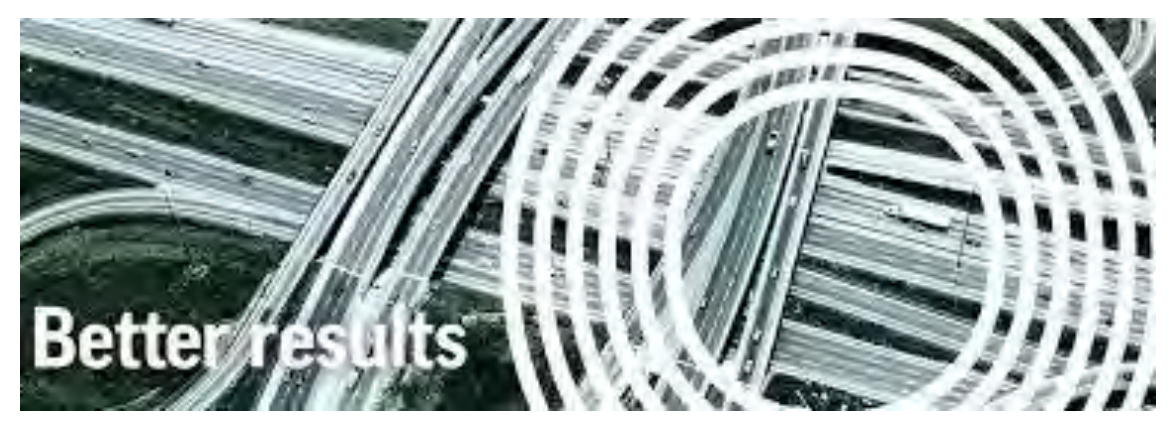

Pegasor Ltd. is also part of the MMEA programme. Pegasor produces sensors that measure fine particles from the air. In Europe, this technology is mainly used to measure exhaust emissions from vehicles, whereas in China it is used to monitor outside air quality in cities. They have grown to become a system supplier. The system includes modelling software that is used to combine measurement data and identify pollution sources.

Pegasor has benefitted most from the pilot studies included in the programme. They feel that the programme and pilot studies are very well managed and played a major role in their increase of exports to China, which now account for $70 \%$ of their annual total sales.

\subsubsection{GreenStream Network Plc}

The GreenStream Network Plc was identified as a success story from The Green Growth Programme funded by Tekes. They are described as a leading Nordic company who focuses on providing carbon asset management and services in climate and renewable energy markets. They have 37 employees and their turnover was EUR 3.5 million in 2012.

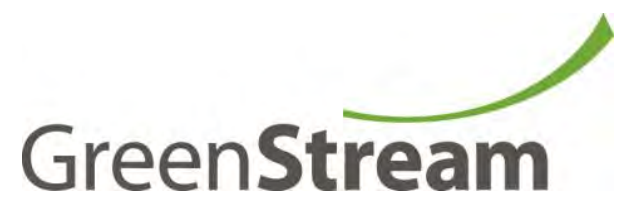


The project started in April 2013 and will continue until the end of 2014. There are seven partners in this project, all of them are considered SMEs and their products range from energy saving expert services to sensor technology. The project develops and sells energy efficiency services for Chinese customers. For this purpose, a network is needed. The project started by providing information on certificates needed in China for those partners that are entering the Chinese markets for the first time.

The funding supports sale and access to the Chinese market, as well as development of new business models. The company feels that the project has created a strong reputation for Finnish environmental technology in general and has found potential partners for long-term cooperation. The programme has really helped build a pathway to enter the Chinese market. Furthermore, the contacts at Tekes have been supportive and flexible; there have been useful discussions with GreenStream Network on how to proceed with the project. At the time of the interview, no results were available.

\subsubsection{The locomotive model in Finland}

To illustrate how the locomotive model works in the Finish context the case of Pegasor Ltd. and Vaisala is presented below. The SME Pegasor has experienced significant export increases, which most likely would not have occurred if the programme had not been in place to provide support. 


\section{Text Box 4. Illustration of the locomotive model in Finland}

\section{Case: Pegasor Ltd. and Vaisala}

\section{Background context}

The Finnish cleantech company Pegasor Ltd. has greatly benefitted from increased exports as a result of participation in "The Measurement, Monitoring and Environmental Assessment" (MMEA) programme. It is a success story in entering the difficult export markets of China and shows the importance of partnerships including both private companies and public organisations. The locomotive company behind the programme, and therefore also the success of Pegasor, is Vaisala.

The sector of both Pegasor and Vaisala is environmental measurement technology, but their products and solutions are in different parts of the value network.

Vaisala is a large locomotive company, which employs 1,500 persons worldwide. The Vaisala Group had a turnover of EUR 293.3 million in 2012. They produce meteorological and environmental measuring technology: measuring devices, instruments and sensors, but they also sell system solutions for several customers, for example road weather systems for road maintenance agencies and weather systems for airports. They also provide weather services for specific purposes, for example for wind power parks. ${ }^{51}$

Pegasor Ltd. is a SME producing sensors that measure fine particles from the air. In Europe, this technology is mainly used to measure exhaust gases from vehicles. In China, it is used to monitor outside air quality in cities. Due to the broad partnership, Pegasor has grown from a sensor and component producer to a producer of instruments and measuring systems and now to a system level company. This growth is mainly due to the Chinese market. Pegasor has ten employees, but they have several subcontractors. They also buy research and development services from research institutes like the Tampere University of Technology (TUT). Their turnover in 2014 is EUR 3 million. 52

The MMEA programme has 30 participating companies and 13 research organisations. The entire programme period has a budget of EUR 50 million. A SME typically covers $50 \%$ of its participation. For large companies the share of public funding is smaller.

51 www.vaisala.com

52 www.pegasor.fi 
The programme was established in 2010. Companies interested in the general topic of environmental measurement technology were asked to come up with more specific research topics together. The research organizations joined the partnership at this point. Altogether, 45 partners joined the partnership, including 30 companies, many of which are SMEs.

The project Vaisala and Pegasor have developed together is called "China Testbed" and it was set up to test new products and to get references for export markets. Both outdoor and indoor air quality is a growing business sector in China. The project developed a mobile application for monitoring air quality based on the measurement of fine particles in the air. By using the application, consumers can follow air quality and share their own observations on mobile devices. The pilot had several partners, including three research organizations and companies like Vaisala, Pegasor, DigiEcoCity, Fatman, Cubio and Dekati.

\section{The model}

The partnership between Vaisala and Pegasor was formed within the MMEA program. Vaisala is the locomotive company. The model is built on strategic business needs and long-term cooperation between Vaisala, research organisations, Pegasor and a few other private companies. Also CLEEN Ltd played an important role by facilitating the MMEA programme and actively creating contacts to Chinese authorities.

The Chinese Market was at first a small part of the partnership. In China, foreign companies may not directly sell services for authorities; Chinese partners are needed. Through the contacts and references of the partnership, three or four trips to China have taken place, each lasting from eight to ten days. These trips have been very important in getting to know partnership members, especially when there have been challenges on the way.

In addition to these common trips, Pegasor has been very active in travelling to China and creating new contacts, which have benefited the whole partnership. Pegasor has been able to enter the difficult markets of China and grow their business there. With the help of this partnership Pegasor has been able to remove the barriers of getting Chinese references and getting the right contacts to deal with the local authorities. 
The partnership, for Vaisala, has resulted in a more efficient cooperation with research partners like the Finnish Meteorological Institute and Technical Research Centre of Finland (VTT). It has also created cooperation with SMEs. This has enabled cooperation and has created purposeful relationships. One concrete result is that Vaisala can now use the technology platform built within the partnership for their own products, which will accelerate the launch of new information service products on various markets. For example, their latest information service applications for aviation and road weather are based on a platform developed within the partnership.

The result of this partnership for the SME Pegasor has been highly significant. Pegasor has grown tremendously by entering the Chinese market. China is now the single most important market for them. Their turnover already in 2014 is EUR 3 million. It was EUR 1-2 million for a long many years prior, and is estimated to rise to EUR 8 million in 2015. In 2013, the share of sales in China was $5 \%$, of the total sales of the company. In 2014, it has grown to approximately $70 \%$. Pegasor is now present in eight provinces in China and there are altogether 32 provinces where they could expand.

\section{Purpose}

The purpose of the partnership for the locomotive Vaisala is to broaden its networks by new long-term cooperation with new partners. Another motivation is the funding the programme enables for the research phase before product development. Both new partners and new products will help Vaisala to grow its business in the future. Developing new solutions and entering new business areas in environmental measurement technology is their vital strategic business need.

The purpose for joining the partnership for Pegasor is to partner with research organizations and get useful research results that can be further developed into new products. The possibility to build demonstrations to test the new products within the partnership is also important.

\section{Trends}

As a continuation of the "China Testbed" the Indoor Air China Demonstration is being carried out at the residence building of the Embassy of Finland in Beijing. The idea is to show that the indoor air quality can be improved to the level comparable to standard indoor air quality of similar building in Finland even if the outside air quality is poor. The demonstration showcases Finnish measurement and filtration technology. Pegasor and Vaisala are involved in this demonstration as well as Beautiful Beijing project members Ahlstrom Oyj (filtration technology) and Airmodus Oy (particle counting). 


\section{Expectations}

The MMEA programme that established this partnership has so far been a great success, thereby providing a case where public authority support can lead to beneficial cooperation between a locomotive company and SMEs. The tremendous growth in Pegasor's exports can be directly traced to this partnership.

Pegasor has benefited from the MMEA programme through public private partnership and through the cooperation with research organizations. Pegasor gets useful research results and can further develop their products in other projects going on parallel to the program. The programme also supported the sales in the form of entering the Chinese markets.

In China, the programme has benefited Vaisala by creating new contacts with potential customers on the air quality side. Previously, their contact was CMA (China Meteorological Agency), but now they have contacts with partners close to local administration that is the end customer of air quality services. They are now considering what kind of business they could be involved with in the air quality market.

Further partnership between the locomotive Vaisala and the SME Pegasor is expected. Vaisala is already partnering with Pegasor in the air quality business in China. Vaisala has a global marketing and sales network. Now they are studying the possibility to have commercial cooperation. Vaisala does not produce air quality sensors or systems, but they produce some components and meteorological systems that are closely linked to air quality.

The partnership may result in opening of a new market in China for Vaisala if the commercial cooperation with Pegasor described above will come true. It has already provided new contacts in China. Again, they did not have any contact before the programme and their project started, further revealing the importance of this public authority funding in achieving cooperation between locomotive companies and SMEs. 


\subsection{Conclusions}

In short, the findings from the consultation with the businesses showed the following trends:

- Companies across the Nordic countries ask for even more business driven public initiatives and support.

- Public support to new product developments, networking and building of new export platforms is experienced as a long process that sometimes lacks public prioritisations and a more business driven approach.

- Companies tend to criticize the public initiative if it becomes too broad and too far from potential (new) markets.

- SMEs need the financial, advisory and network support from public authorities.

- Larger companies are seen as export locomotives for SMEs, but private/public funding and a close cooperation between the companies seems to be needed for creating export success.

- Denmark has a comprehensive set of instruments that support most phases of a company's value chain. Companies interviewed voiced positive results.

- In Denmark, business driven initiatives where high-skilled public sector experts support the small and medium-sized export initiatives have shown to be a success, especially in the wind sector, such as the Wind Energy Advisory (WEA) in Chicago.

- There is a strong focus on early stage support, e.g. RD\&D, in Sweden, Finland and Norway.

- Testing facilities and demonstration projects were highly supported in Sweden and Norway.

- None of the companies complained about too much bureaucracy within the instrument or initiative set-ups.

- Late stage funding, e.g. sales, in especially needed in Sweden and Norway; many companies mentioned this.

- The cases from Finland and Denmark show that support provided in the sales phase of the value chain was done with strong engagement of the public authorities.

- No cooperation between Nordic companies has been identified in the analysis and none of the public programmes has a Nordic focus. 


\section{Conclusions}

The following conclusions are based on the overview of the public initiatives and companies in the Nordic Countries. These are followed by concluding remarks on each of the four Nordic countries. Lastly, conclusions are drawn from the locomotive model and the literature review.

\subsection{Overview of the public initiatives in the Nordic Countries}

The public authorities in Denmark, Norway, Sweden and Finland all support their cleantech sectors. The regulatory set-up varies but the majority of the support comes in form of financial funding, i.e. loans, grants, subsidies. Further assistance comes from advisory services, market analysis and networking. Remarkably, none of the public programmes has a Nordic focus.

In total, ten public cleantech initiatives were identified that clearly supported cleantech and had a further focus on either cooperation between two or more companies, and/or export. These public initiatives mostly focus on individual areas of the value chain, either RD\&D, commercialisation, sale or after service; very few initiatives covers multiple purposes.

The conclusions drawn from the overview of the public initiatives in the Nordic Countries are that:

- The budgets for funding and support are much higher in Norway compared with the rest of Nordic countries.

- The funding in Denmark is more related to the understanding of the value chain of businesses than in the other Nordic countries.

- The instruments used in Sweden and Finland are mainly designed to target early stage support in the value chain (RD\&D).

- There is no use of the term locomotive model or of the term system solution.

- In Denmark, there is a strong focus on water and energy, in Norway on energy, and in Sweden and Finland there is no particular focus. 
- Few of the public initiatives have been evaluated in terms of their purpose and expenditures. The effects of the initiatives are not well investigated and quantitative or qualitative measures were lacking.

Many of the programmes have specific requirements for applicants. Often, they require partnerships between one or more companies, in order to receive funding. This requirement encourages cooperation and sharing of knowledge, either between a large company and SMEs or among a group of SMEs. The instruments rarely have as their specific goal the support of system solutions. However, when more companies cooperate, the product or service is likely to take the form of some degree of system solution.

\subsection{Overview of companies in the Nordic Countries}

Fourteen Nordic companies were identified and their perspectives on the public initiatives and instrument support in creating growth and increasing export share were subsequently assessed. Secondly, a locomotive model was described for each of the Nordic countries in a case study.

The companies' views on the public initiatives and instrument support vary across the Nordic countries. The most positive views are found in the four cases, which show how public initiatives have succeeded in supporting the companies and their locomotive models.

The conclusions on the overview of companies in the Nordic Countries are that:

- Companies across the Nordic countries ask for even more business driven public initiatives and support.

- Public support to new product developments, networking and building of new export platforms is experienced as a long process that sometimes lacks public prioritisations and a more business driven approach.

- Companies tend to criticize the public initiative if it becomes too broad and too far from potential (new) markets.

- SMEs need the financial, advisory and network support from public authorities.

- Larger companies are seen as export locomotives for SMEs, but private/public funding and a close cooperation between the companies seems to be needed for creating export success. 
- Denmark has a comprehensive set of instruments that supports most phases of a company's value chain. Companies interviewed voiced positive results.

- In Denmark, business driven initiatives where high-skilled public sector experts support the small and medium-sized export initiatives have proved to be a success, especially in the wind sector, such as the Wind Energy Advisory (WEA) in Chicago.

- There is a strong focus on early stage support, e.g. RD\&D, in Sweden, Finland and Norway.

- Testing facilities and demonstration projects were highly supported in Sweden and Norway.

- None of the companies complained about too much bureaucracy within the instrument or initiative set-ups.

- Late stage funding, e.g. sales, is especially needed in Sweden and Norway; many companies mentioned this.

- The cases from Finland and Denmark show that support in the sales phase of the value chain was shown by strong engagement of the public authorities.

- No cooperation between Nordic companies was identified in the analysis and none of the public programmes has a Nordic focus.

\subsection{Denmark}

In Denmark, the Environmental Technology Development and Demonstration Programme (MUDP), the Green Transition Fund and the Danish Trade Council have been included in this project. Combined, they are focusing on all parts of the value chain, including RD\&D, commercialisation, sale and after service.

The MUDP provides subsidies for private companies, universities, research institutions and individuals to develop, test, and/or demonstrate environmental technologies and carry out technical feasibility studies. The Green Transition Fund assists in getting products or services to an international market within two years. The Danish Trade Council is responsible for assisting SMEs and large companies in exporting and expanding their activities to new markets by providing strategic sales alliance services.

The Danish companies have positive views on the success of the instruments available, especially when it comes to the business driven support. 
The case from Denmark highlights a new form of public-private partnership that is successfully being carried out in the United States and focuses on first finding a high-growth potential market and then supporting the companies. The case illustrates targeted instruments to support the companies by authorities operating in the export market with multiple aims.

The strength in the Danish case is the highly targeted support that the companies received in the value chain. It also shows how large energy companies have been locomotives for smaller Danish companies that have experienced the growth and business development necessary to become a locomotive themselves for other Danish SMEs.

\subsection{Sweden}

In Sweden, BYGGinnovationen, authorized by Vinnova, and SymbioCity, authorized by Business Sweden, are mainly focusing on the commercialisation and sale parts of the value chain.

BYGGinnovation provides grants to facilitate commercialization of knowledge, solutions and research results within Information and Communication Technology, Process Development and Sustainability. SymbioCity assist in establishing contacts with foreign local policymakers and advocating for certain criteria for construction and procurement of various environmental projects.

Almost all the Swedish companies interviewed mentioned the lack of a comprehensive Swedish national strategy as a barrier to effective, properly targeted public support funding and that too much focus is aimed towards R\&D; commercialisation of green technologies is lacking. Companies, for example, feel that SymbioCity is simply too complex for companies to see what their role is.

\subsection{Norway}

In Norway, public cleantech funding mainly comes from Innovation Norway and Investinor, both funded by the Norwegian Government, and focusing on all parts of the value chain.

Investinor invests in promising companies that wish to grow and expand internationally. The Environmental Technology Scheme (ETS), authorized by Innovation Norway and Investinor's entire investment programme, targets the RD\&D stage of a company's value chain, but 
can also support them financially throughout the commercialisation and sale stages.

Their annual budget is between EUR 470-708 million. Therefore, these authorities are able to support many different areas of a company's value chain in one initiative, and have follow-up services to make sure that the company's stay on track with their strategic goals. This is different from the other Nordic countries, which tend to focus on one phase of the value chain with both financial and qualitative services, e.g. advisory services.

According to the Norwegian companies interviewed, there is still insufficient support in the commercialization stage, and more can be done to reduce risks when expanding production to emerging economies and developing countries. There could be a divide between what public authorities promise through the various initiatives, and what is actually delivered.

The Norwegian case is about Wärtsilä, which is an export company within green maritime technology that focuses on energy saving solutions. Wärtsilä is one of the 31 members of the cluster Maritime CleanTech West (MCTW). The partnership works as a catalyst for feasible green projects. The members of the cluster come from the whole supply chain, and the cluster includes all parts of the Norwegian Maritime industry. Most of the members are businesses, but there is also a university and a naval base. The partnership is currently administrated by Innovasjon Norge; a Norwegian Government instrument for innovation and development of Norwegian enterprises and industry.

\subsection{Finland}

In Finland, public initiatives for cleantech growth are primarily funded through Tekes, the Finnish Funding Agency for Technology and Innovation.

The Green Growth Programme under Tekes funds companies and value networks that have growth potential in resource efficiency technologies. The Strategic Centres for Science, Technology and Innovation (SHOK) promote closer cooperation and interaction between business life and research to speed up innovation processes.

Finnish public authorities have a strong focus on early stage support, more specifically financial funding in research, development, demonstration and testing of cleantech. This is highly beneficial for Finnish companies, who are encouraged to create innovative technologies. However, this early stage funding has received criticism from some inter- 
viewed Finnish companies, as many feel that there is a need for commercializing and selling these technologies in foreign markets.

Finland has begun directing support towards exports and selling these technologies on international markets, which can be seen in the creation of the Export Partner Groups. Furthermore, TEKES established smaller programmes in 2006 to promote closer cooperation and interaction between business and research to speed up the innovation process.

The Finnish case shows an initiative where "matchmaking" was carried out by the public instrument. The companies were matched together based on their competences and they proceeded to the Chinese market together, driven by the business opportunity.

\subsection{Locomotive model}

The locomotive model has been investigated through four cases, one from each Nordic country (Norway, Finland, Sweden and Denmark).

The locomotives investigated here only have one wagon (company) and sometimes a few more, but our examples do not reveal large companies pulling many companies, only a few selected. That being said, the Danish energy company Vestas has brought numerous smaller Danish companies to the U.S. market over the years. Some of the public instruments require a certain amount of participants, in order to obtain funding. This is however not generally required.

To some extent, a number old, large companies still operate as locomotives, but grouping of smaller companies seems to be the trend. The older companies that have exported for many years have built up local networks of suppliers, which they rely on more than national suppliers from their home countries. This also has to do with the identity of the companies and the more globalised employers' base. They just do not feel as Nordic as they used to. The Danish case though shows how a supplying company for Vestas built factories close to the market, in order to operate close by and take on competition with local suppliers.

The support by the Danish authorities targets the needs of the company related to the position of the value chain. The support received was also very practical and concrete compared with many of the other programmes that have been included in this analysis.

To create export success, the companies need to have access to financial and high-skilled public support in each of the phases of the value chain, and the support needs to be business driven. The business opportunity should be the essential driver, not the possibility of obtaining 
support. Otherwise, the understanding of the market will be lacking and the initiative will not be sustainable in the long run.

This being said, the understanding of the specific needs of the companies are essential for creating a successful match of the public instruments and the companies. At the moment, the support is given to broadly to support general objectives more than precise needs.

What can be drawn from the literature is that the support should be given from the public initiatives to both the SMEs and the large companies. Literature suggests designing the public initiatives to support the establishment of the cooperation by providing draft contracts, export-country insights and good example or cases that can be used as inspiration. 



\section{Recommendation}

The following suggestions are given for policy makers in the Nordic countries on how to support and promote the locomotive model, now with an understanding of the interaction between large businesses and SMEs who aim to export cleantech.

\subsection{Focus on finding the correct companies to partner up}

It is crucial for the companies to find the right partners and the public authorities can play an important role in the "match making".

All the cases in this reports show how a good partnership has the potential to create export success stories, and the cases from Sweden and Finland shed light on the importance of public funding in early stage development. Most of the Nordic cleantech funding supports cooperation between companies. However, to support the creation of more locomotives, more public initiatives are needed to link the larger companies to the innovative SMEs.

\subsection{Find markets for prospective sales}

Support to the late stages in the value chain such as commercialization and sale, is just as important as RD\&D support. Creating positive conditions for companies to get their products or services to market is integral for export success.

A main issue mentioned by many Nordic companies was the lack of assistance in the commercialization phase. Especially small or medium sized companies need funding to develop and demonstrate the product or service, but getting it to the right markets is increasingly important. More public authority initiatives should be designed with a specific market or geographical region in mind to which clean technologies can be directed. The Nordic public authorities have a widespread network all over the world through their diplomatic activities. 


\subsection{Focus the design and goal of the export promotion programmes}

Unclear strategic goals and incoherent public initiatives for supporting export make the companies uncertain about how they can obtain support and to what degree.

Very few public initiatives cover multiple parts of the value chain from the RD\&D and commercialisation to sale and after service. To bridge these transitions, a more coherent public support is needed. Companies in most of the Nordic countries experience public initiatives that cover links in the chain but not all. Also, numerous public initiatives can make it difficult for companies to find the right support.

\subsection{Analyse if there are export potentials in strengthening the support of cooperation between Nordic companies and between Nordic public initiatives}

It is remarkable that only limited examples of cooperation between Nordic companies have been identified and that none of the public programmes has a Nordic focus.

Due to the similarities between the Nordic initiatives and the common focus on promoting the export of cleantech, a large potential in resource savings and increased initiative effectiveness could be realized. An analytical approach could be to focus on the potentials of combining initiatives within one or two specific sectors, for example wind, water or waste. This could enable a significant build-up of knowledge, and strengthen these sectors even more in each respective country.

\subsection{Further conceptualisation of and insight into successful locomotive export models}

This analysis has shown that companies can be locomotives and catalysts for small and medium-sized enterprises in exporting cleantech. It has also shown that well-targeted and high-skilled public support can be crucial for the success of the export activities.

Further conceptualisation of and insight into successful locomotive export models can create the basis for even more focused policy initia- 
tives and programmes. This, for example, applies to the company sector focused support from the Danish General Consulate in Chicago, or the "matching making" of the MMEA programme in Finland. Can the success of these models be confirmed when looking at other companies or continents, or are they outstanding examples that are difficult to find elsewhere? Such insight can prove valuable for further policy making across the Nordic countries.

\subsection{Develop tools to support the promotion of system solutions}

The instruments used in the Nordic countries could benefit from being even more precise on how to go about supporting system solutions. The different levels of system solutions need different types of support, just as the different phases of the value chain require different types of assistance. It would be beneficial to explore the needs for the different types of system solutions and design instruments targeted at supporting this form of exporting. The Danish case had some interesting lessons learnt on how export of system solutions can be initiated by public authorities.

\subsection{Provide a broad range of tools allowing for support of all stages of the value chain}

The companies should have access to an instrument in all phases of its value chain, meaning depending on where the company is at in its cleantech development, it should be able to receive support in that stage.

A company will have difficulty increasing its exports if the only initiatives available target RD\&D. Again, it is very important that the aim and goals of the initiative are clear, both for the public authority and for the company. Too often, the instruments are not defined well enough and overlap each other and related to the phases of the value chain that it is targeting. 



\section{References}

\section{From the literature}

Ahuja, G. (2000). The duality of collaboration. Strategic Management Journal, 21(3): 317-343. http://dx.doi.org/10.1002/(SICI)1097-0266(200003)21:3\%3C317::AIDSMJ90\%3E3.0.CO;2-B

Alvarez, S. Barney \& J.B. (2001). How Entrepreneurial Firms Can Benefit from Alliances with Large Partners. The Academy of Management Executive, 15(1): 139-148. http://dx.doi.org/10.5465/AME.2001.4251563

Baum, J., Calabrese, T., \& Silverman, B.S. (2000). Don't go it alone: alliance network composition and startups' performance in Canadian biotechnology. Strategic Management Journal, 21(3): 267-294. http://dx.doi.org/10.1002/(SICI)10970266(200003)21:3\%3C267::AID-SMJ89\%3E3.0.CO;2-8

Dana, L. (2001). Introduction: networks, internationalization and policy. Small Business Economics, 16(2):57-62. http://dx.doi.org/10.1023/A:1011199116576

Das, T.K., \& Teng, B-S. (2002). Alliance constellations: a social exchange perspective. Academy of Management Review, 27(3): 445-456. http://dx.doi.org/10.2307/4134389

Durmusoglu, S., Apfelthaler, G., Zamantili Nayir, D., Alvarez, R., \& Mughan, T. (2012). The effect of government-designed export promotion service use on small and medium-sized enterprise goal achievement: a multidimensional view of export performance. Industrial Marketing management, 41:680-691.

http://dx.doi.org/10.1016/j.indmarman.2011.09.016

Erramilli, M.K., \& Rao, C.P. (1990). Choice of Foreign Market Entry Modes by Service Firms: Role of Market Knowledge. Management International Review, 30(2): 135-150.

European Commission, COM (2004). 38, Stimulating Technologies for Sustainable Development: An Environmental Technologies Action Plan for the European Union.

Gulati, R. (1998). Alliances and networks. Strategic Management Journal, 19(4): 293317. http://dx.doi.org/10.1002/(SICI)1097-0266(199804)19:4\%3C293::AIDSMJ982\%3E3.0.CO;2-M

IVL Svenska Miljöinstitutet (2008). Studie om systemlösningar inom miljöteknikområdet - konsultrapport beställd av Nutek.

Kruger, Morten (2013). Eksport af grøn teknologi og grønne systemløsninger. Miljøministeriet, Miljøstyrelsen, Innovayt. København. Accessed 13th July 2014.

Riksrevisionen (2013). Heading out into the world - the State's initiatives for promoting export (RiR 2013:10).

Speakman, R.E., Isabella, L.A., \& McAvoy, T.C. (2000). Alliance competence: maximizing the value of your partnerships, New York: John Wiley \& Sons.

Street, C. \& Cameron, A-F. (2007). External relationships and the small business: a review of small business alliance and network research, Journal of Small Business Management, 45(2): 239-266.

Tillväxtanalys, (2014). Effekter av statens främjande-insatser för internationalisering - utveckling av mätmetoder och indikatorer. Rapport 2014:07. 
Tillväxtanalys (2012). Statistik om miljösektorn - arbetstillfällen omsättning och export 2003-2011.

Wilkinson, T. \& Brouthers, L.E. (2006). Trade promotion and SME export performance. International Business Review, 15:233-252.

http://dx.doi.org/10.1016/j.ibusrev.2006.03.001

\section{From the internet}

Danish Ministry of the Environment (2013). Accessed 13th July 2014.< http://eng.mim.dk/

Miljøministeriet Ecoinnovation (2014). Tilskudsordning til miljøeffektiv teknologi. Miljøstyrelsen. Accessed 13th July 2014.

http://ecoinnovation.dk/emneoversigt/isaer-for-virksomheder/finansiering-ogtilskud/tilskudsordning-miljoeteknologi-mst/

Erhvervsstyrelsen. Grøn Omstillingsfond (2014). Accessed 13th July 2014. http://groenomstilling.erhvervsstyrelsen.dk/gronomstillingsfond

Danish Business Authority (2014). Accessed 13th July 2014. http://danishbusinessauthority.dk/

Ministry of Foreign Affairs of Denmark (2014). About the Trade Council. Accessed on 13th July 2014. http://um.dk/en/tradecouncil/about/

Vinnova (2014). utlysning Bygginnovationen 2011-2016. Available at http://www.vinnova.se/EffektaXML/ImporteradeUtlysningar/201102947/Utlysning\%20Nationellt\%20innovationsprogram\%20\%20Bygginnovationen_rev20140925.pdf(599759).pdf

www.bygginnovationen.se

www.symbiocity.org/en/approach

Kortlægning af miljøteknologiske virksomheder i Danmark (FORA, 2009): http://ecoinnovation.dk/media/ecoinnovation/64397/ miljoeteknologisk_rapport_online.pdf

http://greetings.um.dk/da/eksportraadet/sektorer/miljoe\%20og\%20vand/

http://www.gogreenwithaarhus.dk/en/Projekter/Vandtestcenter-samler-nationalestyrker.aspx

http://www.gogreenwithaarhus.dk/en/Projekter/Vandtestcenter-samler-nationalestyrker.aspx

Vækstplan for vand, bio og miljøløsninger: http://www.evm.dk/publikationer/ 2013/ /media/oem/pdf/2013/2013-publikationer/12-03-13-vaekstplan-forvand-bio-og-miljoeloesninger.ashx

LEAN Energy Cluster: www.leanenergy.dk/

Strategi for samarbejde om Danmarks klynge- og netværksindsats: http://www.leanenergy.dk/media/161547/cluster_strategy_dk.pdf

www.danskmiljøteknologi.dk/

Miljøstyrelsen, Miljøprojekt (2006). Markedet for miljøeffektiv teknologi: http://www2.mst.dk/common/Udgivramme/Frame.asp?http://www2.mst.dk/Ud giv/publikationer/2006/87-7052-077-1/html/helepubl.htm

http://www.aarhusvand.dk/ 
http://www.danishwaterforum.dk/activities/Eksportfremmeseminar_121213/Lars -Eskil-Jensen_Water\%20Technology\%20Alliance\%20i\%20USA.pdf

www.aluwind.com/company-profile.html

SCB (2014). Miljösektorn per branschgrupp, 2013. Available 20th October 2014 http://www.scb.se/sv_/Hitta-statistik/Statistik-efter-amne/Miljo/Miljoekonomioch-hallbar-utveckling/Miljorakenskaper/38164/38171/Miljosektorn/324496/

www.scania.com/

www.malmberg.se/

www.xylemwatersolutions.com/

www.skanska.com/

www.frigeo.se/

Menon and Intpow Report no 01/2013. The Norwegian Cleantech Industry - Statistics 2011. http://intpow.com/index.php?id=1759\&download=1

www.borregaard.com/

www.greenbiologics.com/

www.prediktor.no/

www.tomra.com

http://www.tomra.com/en/about-us/our-mission

Finpro (2014). Invest in Finland. Industries: Cleantech.

http://www.investinfinland.fi/industries/cleantech/18 Viewed 27.6.2014

Cleantech Finland (2014a). About Cleantech Finland.

http://www.cleantechfinland.com/content/about-cleantech-finland Viewed 27.6.2014

Cleantech Finland (2014b). Development of Cleantech Industry in Finland 2014. 5th Annual Survey of Finnish Cleantech Industry. http://www.slideshare.net/cleantechfinland/ cleantech-industry-in-finland-2014

www.vaisala.com

www.pegasor.fi 



\section{Sammenfatning}

Formålet med dette projekt er at undersøge, hvordan det offentlige kan fremme lokomotivmodellen. Modellen skal forstås som partnerskaber mellem lokomotivvirksomheder og SME'er for at fremme eksporten af cleantech og systemløsninger. Lokomotivvirksomhederne kender ofte SME'erne fra deres eksisterende leverandørkæde.

Den anvendte metode i dette projekt bestod af to trin. Det første var at foretage en analyse af, hvordan de offentlige myndigheders initiativer støtter samarbejde om cleantech løsninger med lokomotivvirksomheder. Derefter blev virksomheder interviewet for at få deres perspektiv på de eksisterende instrumenter. Det andet trin var en kortlægning og analyse af eksisterende lokomotivvirksomheder. Det blev belyst hvordan store virksomheder kan være katalysator for små og mellemstore virksomheder $\mathrm{i}$ at eksportere cleantech. "Best practise" blev anvendt til at inspirere til anbefalinger for udformningen af fremtidige offentlige initiativer.

Litteraturgennemgangen viste at instrumenter til at fremme samarbejdet i eksportfremme mellem store virksomheder og små og mellemstore virksomheder, er meget begrænset behandlet. Fokus har i stedet været på motiver og resultater for disse typer af samarbejder, primært baseret på forskning omkring netværk. Erfaringerne hvis man ønsker at fremme lokomotiver som et middel til at støtte SME'ernes internationalisering, er at støtte både store virksomheder og SME'er i etableringen af et samarbejde, når det gælder vurdering af behov og de komplementære kompetencer hos de deltagende aktører. Erfaringer som politiske beslutningstagere kan anvende er at der er behov for at støtte såvel store som små virksomheder i udformningen af kontrakter; både at definere samarbejdsformen men også for at begrænse store virksomheds adgang til de mindre virksomheders teknologi og ekspertise. En anden lære vedrørende fokus i de eksportfremmende programmer hvis der lægges vægt på levering af "objektiv" viden til eksportører, bør dette genovervejes så der leveres "erfaringsmæssig" viden i stedet som sikre en mere langsigtet samarbejdsform.

Interviewsne med de offentlige myndigheder viste, at valget af instrumenter varierer meget mellem de nordiske lande. Kun i Danmark er instrumenter til rådighed, der er målrettet de enkelte bestemte faser i en 
virksomheds værdikæde. Norge har langt den største budget, hvor den største andel anvendes til forskning, udvikling og demonstration, hvilket svarer til Sverige og Finland. Udformningen af instrumenter med formål at støtte den tidlige fase af værdikæden fremmer en stærk iværksætterkultur. Instrumenterne i Danmark er mere defineret og deres mål er klarere. Dette hjælper virksomheder til at vide, hvilke instrumenter de kan anvende i forskellige faser af deres værdikæde.

Kun få initiativer stiller krav til at der skal være flere ansøger som har udarbejdet en ansøgning endvidere blev det observeret at termerne "lokomotivmodel" og "systemløsning" ikke blev brugt af de offentlige myndigheder.

Der er et stærkt fokus på vand og energi teknologier i Danmark, Norge fokuserer på energi og Sverige og Finland har ikke specifikt fokus for deres finansiering.

En af de vigtigste observation var, at de forskellige initiativer ikke var evalueret i forhold til deres effekt og succes. Der var nogle enkle overvejelser om antallet af virksomheder, der er involveret, og afløb af finansieringen, men få evalueringer vedrørende de kvantitative eller kvalitative resultater.

Interviewsne med virksomhederne viste, at Danmark har et omfattende sæt af instrumenter, som er rettet mod de fleste faser af virksomhedens værdikæde. De interviewede virksomheder har bekræftet, at de instrumenterne, levede op til deres forventninger. I Sverige, Finland og Norge, der er en stor fokus på at finansiere den tidlige fase af værdikæden, hovedsagelig forskning og udvikling. Test faciliteter og demonstrationsprojekter var ligeledes godt understøttet i Sverige og Norge. Interviewsne i Finland og især Sverige og Norge pegede på behovet for at have et instrument til at målrette de senere faser af værdikæden. I Finland var der dog et eksempel hvor det var muligt at modtage støtte i forbindelse med salgsfasen af værdikæden. Ingen af virksomhederne nævnte at de var utilfredse med bureaukratiet bag initiativerne eller instrumenterne.

Følgende anbefalinger er derfor baseret på disse observationer og angiver, hvordan instrumenterne kan designes til at understøtte cleantech-virksomheder $\mathrm{i}$ at komme ud på eksportmarkederne sammen.

Følgende forslag til inspiration til beslutningstagerne kan foreslås til hvordan lokomotivmodellen og eksport af systemløsninger kan fremmes gennem design af instrumenter og forståelse af samspillet mellem store virksomheder og små og mellemstore virksomheder, som ønsker at eksportere cleantech: 
- Fokus på at finde de rigtige virksomheder til at samarbejde med.

- Find markeder for potentielle salg.

- Fokus på design og mål af eksportfremmende initiativer.

- Analysere, af eksport potentialer for at styrke samarbejdet mellem nordiske virksomheder og mellem de nordiske offentlige initiativer.

- Giv en bred vifte af redskaber til at støtte alle led i værdikæden.

- Yderligere konkretisering af og indsigt i hvad en vellykkede lokomotiv eksportmodel er.

- Udvikle værktøjer til at støtte fremme af systemløsninger. 
Ved Stranden 18

DK-1061 Copenhagen K

www.norden.org

\section{Locomotive business}

This report explores how public sector support promotes the locomotive model, which is understood as partnerships between locomotive companies and SMEs in order to facilitate export of cleantech and system solutions. Support structures vary a lot among the Nordic countries. A main observation is that the various programmes in all Nordic countries had little information on the impacts of the instruments. Some suggestions for policy makers in the Nordic countries are offered, now with an understanding of the interaction between large businesses and SMEs, which wish to export clean technologies. The project was carried out from May 2014 to December 2014 by a consortium led by COWI with FORES, Swedish Entrepreneurship Forum and Tyrsky Consulting as partners. The Nordic Council of Ministers' Working Group on Sustainable Consumption and Production initiated and financed the project.

TemaNord 2015:532

ISBN 978-92-893-4078-6 (PRINT)

ISBN 978-92-893-4080-9 (PDF)

ISBN 978-92-893-4079-3 (EPUB)

ISSN 0908-6692

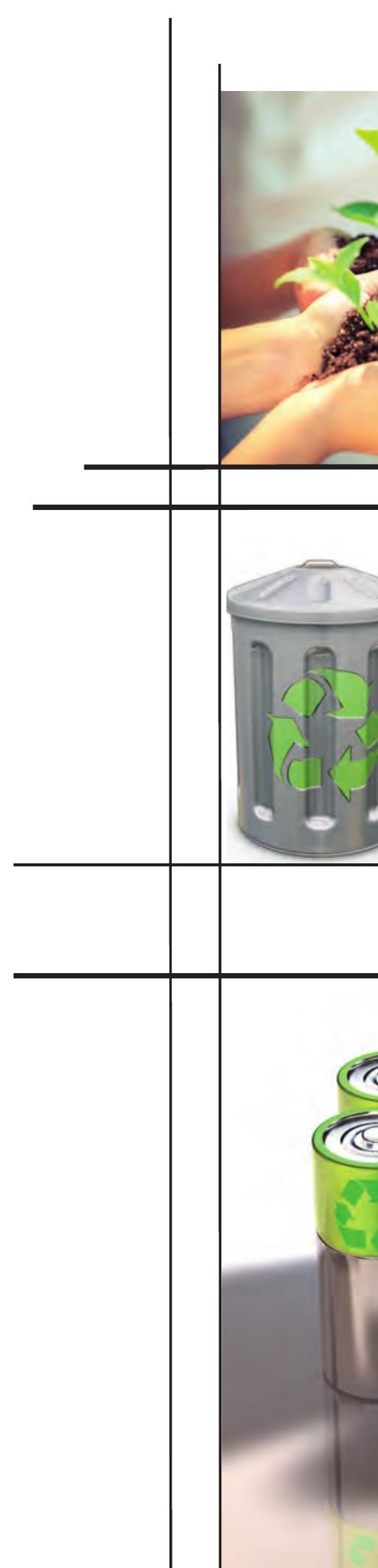

